\title{
Maceration Before and During Fermentation: Effect on Pinotage Wine Phenolic Composition, Total Antioxidant Capacity and Objective Colour Parameters*
}

\author{
D. de Beer ${ }^{1}$, E. Joubert ${ }^{1,2}, * *$, J. Marais $^{2}$ and M. Manley ${ }^{1}$
}

(1) Department of Food Science, Stellenbosch University, Private Bag X1, 7602 Matieland (Stellenbosch), South Africa; DBeerD@arc.agric.za,mman@sun.co.za

(2) ARC Infruitec-Nietvoorbij (Fruit, Vine and Wine Institute of the Agricultural Research Council), Private Bag X5026, 7599 Stellenbosch, South Africa; JoubertL@arc.agric.za, MaraisJ@arc.agric.za,VSchalkwykD@arc.agric.za

Date of submission for publication: July 2006

Date of acceptance for publication: September 2006

Key Words: Antioxidants, free radical scavenging, juice/skin mixing techniques, phenolic compounds, pre-fermentation maceration.

\begin{abstract}
Low-temperature maceration treatments $\left(1,2\right.$ and 4 days at 10 and $\left.15^{\circ} \mathrm{C}\right)$ before fermentation and juice/skin mixing treatments (punching-down, pumping-over and rotor action every hour and every 3 hours) during fermentation were investigated in terms of their effects on Pinotage wine phenolic composition, total antioxidant capacity (TAC) and colour over three vintages (2000 to 2002). Results for pre-fermentation maceration were not consistent between vintages. Very few significant differences in the phenolic content, TAC and objective colour parameters were observed between the control wines and wines subjected to different pre-fermentation maceration treatments. Pre-fermentation maceration, especially at $15^{\circ} \mathrm{C}$, resulted in wines with increased vitisin A content. Improvement of wine quality when using pre-fermentation maceration treatments at $10^{\circ} \mathrm{C}$ was noted previously, while no detrimental effect on the wine TAC was observed. The pumping-over treatment yielded wines with lower TAC and phenol content, as well as less favourable objective colour values, indicating that the punching-down or rotor treatment would be preferred. Although mixing at hourly intervals yielded a higher content of some phenolic compounds compared to the 3-hour interval mixing, mixing frequency did not affect the TAC of the wine. The objective colour parameters, $h^{*}$ and $b^{*}$, were slightly lower at the higher mixing frequency in 2002 indicating a shift in the direction of a magenta hue.
\end{abstract}

Consumers are becoming more aware of the possible health benefits afforded by dietary antioxidants, such as phenolic compounds occurring in grapes and wine. The enhancement of red wine antioxidant capacity may, therefore, be of value. Increasing phenolic concentration will increase the antioxidant capacity of wines, but can also negatively affect their sensory quality. Higher antioxidant capacity will also increase the capacity of a wine to consume oxygen.

Maceration, i.e. extraction of components from grape solids, is one of the most important processes that give red wine its characteristic taste and flavour profile, differentiating it from white wine (Ribéreau-Gayon et al., 1999). Primarily phenolic compounds are extracted, which contribute to wine colour and structure. Other components released into the wine during maceration include aroma compounds, aroma precursors, nitrogen compounds, polysaccharides and minerals. Control of the maceration process is essential to ensure a good balance between the wine components. As a large proportion of the phenolic compounds found in red wines originated from the skins and seeds (Sun et al., 1999; Sun et al., 2001), maceration has a substantial effect on the antioxidant capacity of red wines (Villaño et al., 2006). The absence (before fermentation) and presence (during fermenta- tion) of ethanol during maceration greatly affects the compounds that are preferentially extracted (González-Manzano et al., 2004).

Pre-fermentation maceration is used to enhance wine aroma in red, rosé and white wines through the increased aqueous extraction of aroma precursors from the grape skins (Marais \& Rapp, 1988; McMahon et al., 1999; Salinas et al., 2005). However, decreased concentrations of acetate and ethyl esters have been reported for pre-fermentation low-temperature skin contact at $15^{\circ} \mathrm{C}$ for 2 and 4 days compared to a control fermented immediately after crushing (Marais, 2003a). Pre-fermentation skin contact at $10^{\circ} \mathrm{C}$ increased the sensory quality of Pinotage wines compared to the control wine for three separate vintages (Marais, 2003a). Pre-fermentation maceration at 10 and $15^{\circ} \mathrm{C}$ enhanced the colour and anthocyanin content of red (Heatherbell et al., 1997; Watson et al., 1997; Reynolds et al., 2001; Gómez-Míguez et al., 2006) and rosé (Salinas et al., 2003; Salinas et al., 2005) wines. Differences in anthocyanin content between treated and untreated wines, however, decreased with ageing (Heatherbell et al., 1997). The extraction of flavan-3-ols and tannins during the pre-fermentation maceration in the absence of ethanol is expected to be relatively low (González-Manzano et al., 2004). The stilbene content

\footnotetext{
* Part of work submitted for a PhD in Food Science at Stellenbosch University, 2006.

** Corresponding author

Acknowledgements: Winetech, the National Research Foundation (NRF) and the Technology and Human Resources for Industry Programme (THRIP) for financial support. Frikkie Calitz of the Biometry Unit, ARC Infruitec-Nietvoorbij for statistical analysis of data.
} 
of wines, made with pre-fermentation low-temperature maceration, was shown to be higher compared to those made without prefermentation maceration (Poussier et al., 2003; Clare et al., 2004).

Juice/skin mixing techniques such as punching-down, pumping-over and rotor action are used during fermentation to ensure good contact between the juice and skins for optimum extraction of aroma, flavour and phenolic compounds. In the presence of ethanol, phenolic compounds such as monomeric and polymeric flavan-3-ols, as well as anthocyanins, are extracted from the grape skins and seeds (González-Manzano et al., 2004). The punching-down and rotor treatments resulted in Pinotage wines with higher sensory quality scores than the pumping-over treatment for three separate vintages (Marais, 2003b). Mechanical pumping-over in closed tanks gave Pinot noir, Dornfelder and Portugieser wines with a different phenolic composition than a mechanical punching-down or rotor action in closed tanks (depending on the cultivar) (Fischer et al., 2000). Similar results were also obtained by Leone et al. (1983) for Sangiovese, Primitivo and Negramaro wines using mechanical pumping-over and punching-down treatments. An hourly pumping-over and twice daily rotor action resulted in Vinhão wines with differences in their colour, anthocyanin content and colour stability (CastilloSánchez et al., 2006). The type of mixing action can therefore also be expected to affect the antioxidant capacity of red wines.

The aim of the study was to investigate the effect of different maceration techniques before and during fermentation on the total antioxidant capacity and colour of Pinotage wines. The effect of the treatments on the phenolic composition of wines was determined to explain differences in total antioxidant capacity and colour. The results were related to the sensory results obtained in a parallel study on the same wines (Marais, 2003a; b).

\section{MATERIALS AND METHODS}

\section{Pre-fermentation maceration}

Grapes were harvested in a healthy condition from one vineyard at Nietvoorbij farm (Stellenbosch, South Africa) at $\sim 23$ to $24^{\circ} \mathrm{B}$ and pH 3.2 to 3.3 in 2000, 2001 and 2002. Pre-fermentation treatments and winemaking were done as described by Marais (2003a). Briefly, the grapes were divided into two equal representative batches and stored overnight at 10 and $15^{\circ} \mathrm{C}$, respectively. After storage, each batch was divided into three equal, representative lots for the three different pre-fermentation treatments. The treatments (in triplicate) were 1 day, 2 days and 4 days skin contact, respectively. Each treatment was carried out with $60 \mathrm{~kg}$ of grapes after destemming, crushing and addition of $80 \mathrm{mg} \mathrm{SO}_{2} / \mathrm{L}$. After the pre-fermentation maceration treatments were completed, the wines were produced according to the standard winemaking protocol with no wood contact (described in De Beer et al., 2006a) at the experimental cellar of ARC Infruitec-Nietvoorbij. Fermentation was completed after $\sim 4$ days. A control wine was prepared with the same standard winemaking protocol, without a pre-fermentation maceration step. After bottling, the wines were stored at $15^{\circ} \mathrm{C}$. Eight months after production, aliquots of each wine were frozen at $-20^{\circ} \mathrm{C}$, to prevent further phenolic changes, until analyses could be carried out. Samples were analysed immediately after defrosting.

\section{Juice/Skin Mixing during Maceration}

Grapes were harvested in a healthy condition from the same vineyard that was used for the pre-fermentation maceration treat- ments at Nietvoorbij farm at $\sim 23$ to $24^{\circ} \mathrm{B}$ and $\mathrm{pH} 3.2$ to 3.3 in 2000, 2001 and 2002. Juice/skin mixing treatments and winemaking were done as described by Marais (2003b). Briefly, winemaking was carried out according to the standard winemaking protocol with no wood contact (described in De Beer et al., 2006a) at the experimental cellar of ARC Infruitec-Nietvoorbij. All the skins and juice obtained after crushing were used for fermentation. During fermentation three mixing treatments were conducted, i.e. manual punching-down of the cap, pumping-over of the juice (imitated by racking the juice into a bucket and pouring it over the skins) and rotor action (imitated by rolling a closed drum filled with the crushed grapes, once to and fro by hand over a $5 \mathrm{~m}$ distance). Each treatment was conducted at two frequencies, i.e. every hour and every 3 hours (in triplicate), between 7:00 and 19:00 until completion of fermentation after $\sim 4$ days. Each treatment was carried out with $60 \mathrm{~kg}$ of grapes. After bottling, the wines were stored at $15^{\circ} \mathrm{C}$. Eight months after production, aliquots of each wine were frozen at $-20^{\circ} \mathrm{C}$ to prevent further phenolic changes until analyses could be carried out. Samples were analysed immediately after defrosting.

\section{Chemicals and phenolic reference standards}

Chemicals and phenolic reference standards used for phenolic and antioxidant analyses were described in De Beer et al. (2006b).

\section{Spectrophotometric analysis of phenolic content}

Pinotage wines from all vintages and treatments were subjected to spectrophotometric analysis of the major phenolic groups. Total phenol, total flavan-3-ol, as well as monomeric, polymeric and total anthocyanin contents were determined in triplicate using the Folin-Ciocalteau (Singleton \& Rossi, 1965), dimethylaminocinnamaldehyde (DAC) (McMurrough \& McDowell, 1978) and pH shift (Ribéreau-Gayon \& Stonestreet, 1965) assays, respectively, as modified and described in De Beer et al. (2006b).

\section{HPLC Analysis of phenolic composition}

Individual phenolic compounds, as well as coloured and noncoloured polymers detected at 520 and $280 \mathrm{~nm}$, respectively, were quantified in duplicate in Pinotage wines from the 2001 and 2002 vintages using an HPLC method (Peng et al., 2002), modified and described in De Beer et al. (2006a). Polymers included polymeric phenolic compounds with 5 or more subunits, consisting of anthocyanins and flavan-3-ols for coloured polymers, and only flavan-3-ols for non-coloured polymers.

\section{ABTS Radical cation scavenging assay}

The total antioxidant capacity (TAC) of Pinotage wines from all vintages and treatments was measured $\left(\mathrm{TAC}_{\mathrm{M}}\right)$ in triplicate using the $\mathrm{ABTS}^{\bullet+}$ scavenging assay (Re et al., 1999). The content of individual phenolic compounds, measured by HPLC, and their experimental Trolox equivalent antioxidant capacity (TEAC) values (reported in De Beer et al., 2006a) were used to calculate the theoretical TAC $\left(\mathrm{TAC}_{\mathrm{CAL}}\right)$. The remaining TAC $\left(\mathrm{TAC}_{\mathrm{R}}\right)$ is the difference between $\mathrm{TAC}_{\mathrm{M}}$ and $\mathrm{TAC}_{\mathrm{CAL}}$. Analysis and calculations were carried out as described in De Beer et al. (2006a).

\section{Objective colour parameters}

The objective colour parameters of Pinotage wines from all vintages and treatments were measured in duplicate on the CIELab scale, namely $a^{*}$ (red/green chromaticity), $b^{*}$ (yellow/blue chromaticity) and $L^{*}$ (lightness), and the $C^{*}$ (chroma) and $h^{*}$ (hue 
angle), calculated as described in De Beer et al. (2006b). Names for hues were adapted from Gonnet (1999) based on the $h^{*}$ values and are described in De Beer et al. (2006b).

\section{Statistical analysis}

Analysis of variance was performed on the means for different treatment combinations to determine whether significant differences occurred. The Student $t$-LSD test $(\mathrm{P}<0.05)$ was used to determine the statistical differences between means. Analysis of variance and difference testing were done using the SAS version 8 software package (SAS Institute Inc., Cary, NC). Pearson product moment correlation coefficients between parameters and their P-values were calculated using the STATISTICA 6 software package (StatSoft, Inc., Tulsa, OK).

\section{RESULTS}

\section{Vintage-related variation}

Vintage-related variation was observed in terms of phenolic composition, antioxidant capacity and objective colour parameters with different trends for the pre-fermentation maceration and juice/skin mixing trials, except for the total phenol, monomeric and polymeric anthocyanin ( $\mathrm{pH}$ shift) contents giving similar trends for both trials (Tables 1,2). Data for each trial are thus presented separately for each vintage.

The 2000 wines had the lowest monomeric and total anthocyanin contents ( $\mathrm{pH}$ shift) when considering the pre-fermentation maceration trial (Table 1). The monomeric anthocyanin content of the 2001 and 2002 wines were 73 and $88 \%$, respectively, higher than that of the 2000 wines, while the total anthocyanin content of the 2001 and 2002 wines were 61 and 57\%, respectively, higher than that of the 2000 wines. The highest polymeric anthocyanin content (pH shift) was observed for the 2001 wines, which was 27 and $80 \%$ higher than the contents observed for the 2000 and 2002 wines. The total flavan-3-ol (DAC) contents of the 2001 wines were 14 and $28 \%$ higher that that of the 2000 and 2002 wines, respectively. The 2001 wines had the highest total phenol contents, which was $20 \%$ higher than that of the 2000 and 2001 wines. The same general trend was observed for both trials. The individual phenolic compounds were only quantified for the 2001 and 2002 wines (Table 2). Of the anthocyanins, only four showed significant differences between the vintages in the pre-fermentation maceration trial, i.e. vitisin A and malvidin-3-acetylglucoside (Glc-Ac) were present at 25 and $8 \%$ lower concentrations, respectively, and peonidin-3-glucoside (Glc) and peonidin-3-Glc-Ac at 11 and $8 \%$ higher concentrations in the 2002 wines. In the juice/skin mixing trial all the monoglucosides and some of the acylated anthocyanins (peonidin-3-Glc-Ac, malvidin-3-Glc-Ac, malvidin-3-p-coumaroylglucoside (Glc-Coum)) were between 16 and $38 \%$ higher in the 2002 wines compared to the 2001 wines. An opposite trend was observed for the vitisin A content, which was $32 \%$ lower in the 2002 wines. The 2001 wines, however, had a 16\% higher monomeric anthocyanin content (HPLC) than the 2002 wines.

The remaining phenolic compounds, or groups of compounds, were largely in 11 to $57 \%$ lower concentrations in the 2002 wines, with wines from the pre-fermentation maceration trial more affected by vintage than wines from the juice/skin mixing trial (see Table 2). Exceptions were quercetin, which was not affected by vintage (pre-fermentation maceration trial) or was present in a $66 \%$ higher concentration in the 2002 wines

\section{TABLE 1}

Vintage-related variation in phenolic composition (measured spectrophotometrically), antioxidant capacity and objective colour parameters of the 2000, 2001 and 2002 Pinotage wines ${ }^{\mathrm{a}}$.

\begin{tabular}{|c|c|c|c|c|c|c|}
\hline \multirow[t]{2}{*}{ Parameter } & \multicolumn{3}{|c|}{ Pre-fermentation maceration treatments } & \multicolumn{3}{|c|}{ Juice/skin mixing treatments } \\
\hline & 2000 & 2001 & 2002 & 2000 & 2001 & 2002 \\
\hline \multicolumn{7}{|l|}{ Phenolic composition } \\
\hline Total phenols ${ }^{b}$ & $2252.4 b^{c}( \pm 147.5)^{d}$ & 2698.0 a $( \pm 194.3)$ & $2334.1 \mathrm{~b}( \pm 151.8)$ & $2056.3 \mathrm{~b}( \pm 196.0)$ & 2698.7 a $( \pm 148.9)$ & $2113.3 \mathrm{~b}( \pm 187.4)$ \\
\hline Monomeric anthocyanins ${ }^{\mathrm{e}}$ & 207.0 c $( \pm 20.0)$ & $358.5 \mathrm{~b}( \pm 29.8)$ & 389.3 a $( \pm 32.7)$ & $185.0 \mathrm{c}( \pm 18.3)$ & $345.5 \mathrm{~b}( \pm 21.8)$ & 368.6 a $( \pm 37.1)$ \\
\hline Polymeric anthocyanins ${ }^{\mathrm{e}}$ & $75.0 \mathrm{~b}( \pm 11.1)$ & 94.9 a $( \pm 9.8)$ & $52.5 \mathrm{c}( \pm 8.3)$ & $77.7 \mathrm{~b}( \pm 11.0)$ & $97.3 \mathrm{a}( \pm 10.7)$ & $44.1 \mathrm{c}( \pm 8.4)$ \\
\hline Total anthocyanins ${ }^{\mathrm{e}}$ & $282.0 \mathrm{~b}( \pm 27.3)$ & $453.2 \mathrm{a}( \pm 35.1)$ & $441.5 \mathrm{a}( \pm 39.2)$ & 257.7 c $( \pm 27.8)$ & 442.8 a $( \pm 29.5)$ & $412.7 \mathrm{~b}( \pm 43.1)$ \\
\hline Total flavan-3-ols ${ }^{\mathrm{f}}$ & $168.6 \mathrm{~b}( \pm 14.1)$ & $193.0 \mathrm{a}( \pm 17.1)$ & $150.9 \mathrm{c}( \pm 10.4)$ & $158.6 \mathrm{c}( \pm 20.9)$ & 207.0 a $( \pm 15.4)$ & $170.1 \mathrm{~b}( \pm 18.6)$ \\
\hline \multicolumn{7}{|l|}{ Antioxidant capacity } \\
\hline $\mathrm{TAC}_{\mathrm{M}^{\mathrm{g}}}^{\mathrm{g}}$ & $13.61 \mathrm{~b}( \pm 1.25)$ & $15.59 \mathrm{a}( \pm 1.51)$ & $15.26 \mathrm{a}( \pm 0.95)$ & $11.87 \mathrm{c}( \pm 1.45)$ & $15.69 \mathrm{~b}( \pm 0.75)$ & $16.85 \mathrm{a}( \pm 1.46)$ \\
\hline $\mathrm{TAC}_{\mathrm{CAL}}{ }^{\mathrm{h}}$ & na & $2.01 \mathrm{a}( \pm 0.21)$ & $1.80 \mathrm{~b}( \pm 0.11)$ & na & $1.62 \mathrm{~b}( \pm 0.11)$ & $1.80 \mathrm{a}( \pm 0.12)$ \\
\hline $\mathrm{TAC}_{\mathrm{R}}^{\mathrm{i}}$ & na & 13.58 a $( \pm 1.46)$ & 13.42 a $( \pm 0.89)$ & na & $14.07 \mathrm{~b}( \pm 0.69)$ & $15.05 \mathrm{a}( \pm 1.39)$ \\
\hline \multicolumn{7}{|c|}{ Objective colour parameters } \\
\hline$C^{* j}$ & $58.05 \mathrm{c}( \pm 2.71)$ & $61.59 \mathrm{~b}( \pm 1.69)$ & $79.56 \mathrm{a}( \pm 3.14)$ & $57.77 \mathrm{c}( \pm 3.58)$ & $62.49 \mathrm{a}( \pm 1.33)$ & $59.79 \mathrm{~b}( \pm 3.54)$ \\
\hline$h^{* k}$ & $16.23 \mathrm{~b}( \pm 1.66)$ & $14.05 \mathrm{c}( \pm 1.63)$ & 28.19 a $( \pm 1.47)$ & 17.16 a $( \pm 1.46)$ & $14.48 \mathrm{~b}( \pm 1.71)$ & $12.03 \mathrm{c}( \pm 1.75)$ \\
\hline $\mathrm{L}^{* 1}$ & $41.27 \mathrm{~b}( \pm 4.36)$ & $36.70 \mathrm{c}( \pm 3.78)$ & 52.46 a $( \pm 4.29)$ & $41.00 \mathrm{a}( \pm 5.29)$ & $35.13 \mathrm{~b}( \pm 4.29)$ & $41.85 \mathrm{a}( \pm 5.00)$ \\
\hline$a^{* m}$ & $55.70 \mathrm{c}( \pm 2.23)$ & $59.72 \mathrm{~b}( \pm 1.34)$ & $70.74 \mathrm{a}( \pm 2.09)$ & $55.17 \mathrm{c}( \pm 3.27)$ & 60.47 a $( \pm 0.94)$ & $58.44 \mathrm{~b}( \pm 3.21)$ \\
\hline$b^{* n}$ & $16.28 \mathrm{~b}( \pm 2.29)$ & $14.98 \mathrm{c}( \pm 2.02)$ & $37.52 \mathrm{a}( \pm 0.80)$ & $17.07 \mathrm{a}( \pm 2.06)$ & $15.64 \mathrm{~b}( \pm 2.09)$ & $12.53 \mathrm{c}( \pm 2.34)$ \\
\hline
\end{tabular}

${ }^{\mathrm{a}}$ means taken over all treatment combinations for a specific vintage; ${ }^{\mathrm{b}} \mathrm{mg}$ gallic acid equivalents/L; ${ }^{\mathrm{c}}$ different letters in a row pertaining to a specific trial denote significant differences $(\mathrm{P}<0.05) ;{ }^{\mathrm{d}}$ standard deviation; ${ }^{\mathrm{e}} \mathrm{mg}$ malvidin-3-glucoside equivalents/L; ${ }^{\mathrm{f}} \mathrm{mg}(+)$-catechin equivalents/L; ${ }^{\mathrm{g}}$ total antioxidant capacity in mM Trolox equivalents; ${ }^{\mathrm{h}}$ total antioxidant capacity in $\mathrm{mM}$ Trolox equivalents as calculated from the content of monomeric phenolic compounds and their Trolox equivalent antioxidant capacity; ${ }^{\mathrm{i}} \mathrm{TAC}_{\mathrm{R}}=\mathrm{TAC} \mathrm{M}-\mathrm{TAC} \mathrm{CAL} ;{ }^{\mathrm{j}}$ chroma; ${ }^{\mathrm{k}}$ hue angle $\left({ }^{\circ}\right) ;{ }^{1}$ lightness; ${ }^{\mathrm{m}}$ red/green chromaticity; ${ }^{\mathrm{n}}$ yellow/blue chromaticity; na $=$ not available. 
TABLE 2

Vintage-related variation in phenolic composition (measured by HPLC) of the 2001 and 2002 Pinotage wines ${ }^{\mathrm{a}}$.

\begin{tabular}{|c|c|c|c|c|}
\hline \multirow[t]{2}{*}{ Compound/Phenolic group } & \multicolumn{2}{|c|}{ Pre-fermentation maceration treatments } & \multicolumn{2}{|c|}{ Juice/skin mixing treatments } \\
\hline & 2001 & 2002 & 2001 & 2002 \\
\hline \multicolumn{5}{|l|}{ Anthocyanins } \\
\hline Dp-3-Glc & $10.35 \mathrm{a}^{\mathrm{b}}( \pm 1.55)^{\mathrm{c}}$ & $10.21 \mathrm{a}( \pm 1.20)$ & $6.59 \mathrm{~b}( \pm 1.12)$ & $8.31 \mathrm{a}( \pm 1.26)$ \\
\hline Pt-3-Glc & $14.97 \mathrm{a}( \pm 2.13)$ & $14.78 \mathrm{a}( \pm 1.38)$ & $10.33 \mathrm{~b}( \pm 1.43)$ & $12.62 \mathrm{a}( \pm 1.52)$ \\
\hline Pn-3-Glc & $5.09 \mathrm{~b}( \pm 0.75)$ & 5.66 a $( \pm 0.72)$ & $3.25 \mathrm{~b}( \pm 0.64)$ & $4.50 \mathrm{a}( \pm 0.85)$ \\
\hline Mv-3-Glc & $188.91 \mathrm{a}( \pm 22.84)$ & $187.93 \mathrm{a}( \pm 13.94)$ & $145.50 \mathrm{~b}( \pm 18.43)$ & $171.42 \mathrm{a}( \pm 16.41)$ \\
\hline Dp-3-Glc-Ac ${ }^{d}$ & $3.92 \mathrm{a}( \pm 0.41)$ & $3.78 \mathrm{a}( \pm 0.30)$ & $2.27 \mathrm{a}( \pm 0.34)$ & $2.32 \mathrm{a}( \pm 0.28)$ \\
\hline Vitisin $A^{d}$ & $11.31 \mathrm{a}( \pm 2.71)$ & $8.50 \mathrm{~b}( \pm 2.21)$ & $8.84 \mathrm{a}( \pm 3.17)$ & $6.03 \mathrm{~b}( \pm 1.75)$ \\
\hline Pt-3-Glc-Ac ${ }^{\mathrm{d}}$ & $3.29 \mathrm{a}( \pm 0.60)$ & $3.24 \mathrm{a}( \pm 0.25)$ & $1.92 \mathrm{a}( \pm 0.29)$ & $2.02 \mathrm{a}( \pm 0.23)$ \\
\hline Pn-3-Glc-Ac ${ }^{d}$ & $4.48 \mathrm{~b}( \pm 0.40)$ & $4.86 \mathrm{a}( \pm 0.36)$ & $2.96 \mathrm{~b}( \pm 0.31)$ & $3.60 \mathrm{a}( \pm 0.41)$ \\
\hline Mv-3-Glc-Ac ${ }^{\mathrm{d}}$ & $60.83 \mathrm{a}( \pm 7.50)$ & $55.84 \mathrm{~b}( \pm 4.65)$ & $47.07 \mathrm{~b}( \pm 5.89)$ & $51.21 \mathrm{a}( \pm 4.65)$ \\
\hline Mv-3-Glc-Coum ${ }^{\mathrm{d}}$ & $28.40 \mathrm{a}( \pm 5.90)$ & 27.86 a $( \pm 3.39)$ & $19.34 \mathrm{~b}( \pm 3.26)$ & $24.87 \mathrm{a}( \pm 3.51)$ \\
\hline Total monomeric anthocyanins $\mathrm{e}^{\mathrm{e}}$ & $331.57 \mathrm{a}( \pm 39.43)$ & $322.66 \mathrm{a}( \pm 23.63)$ & $248.06 \mathrm{~b}( \pm 27.77)$ & $286.89 \mathrm{a}( \pm 27.26)$ \\
\hline Coloured polymers ${ }^{\mathrm{f}}$ & $14.07 \mathrm{a}( \pm 3.38)$ & $10.65 \mathrm{~b}( \pm 2.03)$ & $6.79 \mathrm{a}( \pm 2.25)$ & 7.98 a $( \pm 1.75)$ \\
\hline \multicolumn{5}{|l|}{ Flavonols } \\
\hline Unknown flavonolg & $21.11 \mathrm{a}( \pm 3.30)$ & $10.33 \mathrm{~b}( \pm 1.92)$ & $17.51 \mathrm{a}( \pm 2.32)$ & $9.78 \mathrm{~b}( \pm 2.23)$ \\
\hline Q-3-Glc & $17.42 \mathrm{a}( \pm 2.77)$ & $7.49 \mathrm{~b}( \pm 0.85)$ & $15.55 \mathrm{a}( \pm 2.18)$ & $7.51 \mathrm{~b}( \pm 0.98)$ \\
\hline Q-3-Rham & $11.66 \mathrm{a}( \pm 1.47)$ & $9.30 \mathrm{~b}( \pm 0.82)$ & $10.05 \mathrm{a}( \pm 1.25)$ & $8.70 \mathrm{~b}( \pm 0.94)$ \\
\hline Quercetin & $2.57 \mathrm{a}( \pm 0.90)$ & $3.10 \mathrm{a}( \pm 0.75)$ & $1.84 \mathrm{~b}( \pm 0.32)$ & $3.05 \mathrm{a}( \pm 0.90)$ \\
\hline Kaempferol & $0.72( \pm 0.25)$ & data not shown ${ }^{\mathrm{h}}$ & $0.50 \mathrm{a}( \pm 0.09)$ & $0.23 \mathrm{~b}( \pm 014)$ \\
\hline Isorhamnetin & data not shown ${ }^{\mathrm{h}}$ & data not shown ${ }^{\mathrm{h}}$ & data not shown ${ }^{\mathrm{h}}$ & $0.30( \pm 0.15)$ \\
\hline Total flavonols ${ }^{\mathrm{e}}$ & $32.37 \mathrm{a}( \pm 4.78)$ & $20.12 b( \pm 2.38)$ & $45.45 \mathrm{a}( \pm 5.52)$ & $29.56 \mathrm{~b}( \pm 4.65)$ \\
\hline \multicolumn{5}{|l|}{ Phenolic acids } \\
\hline Gallic acid & $14.04 \mathrm{a}( \pm 1.74)$ & $12.82 \mathrm{~b}( \pm 1.25)$ & $13.45 \mathrm{a}( \pm 1.10)$ & $12.96 \mathrm{a}( \pm 1.49)$ \\
\hline Caftaric acid & $212.88 \mathrm{a}( \pm 44.84)$ & $173.92 \mathrm{~b}( \pm 22.31)$ & $176.75 \mathrm{~b}( \pm 25.43)$ & $207.34 \mathrm{a}( \pm 30.42)$ \\
\hline Caffeic acid & $0.90 \mathrm{a}( \pm 0.23)$ & $0.67 \mathrm{~b}( \pm 0.14)$ & $1.25 \mathrm{a}( \pm 0.13)$ & $1.36 \mathrm{a}( \pm 0.75)$ \\
\hline Coutaric acid ${ }^{\mathrm{i}}$ & $24.01 \mathrm{a}( \pm 5.20)$ & $16.64 \mathrm{~b}( \pm 2.07)$ & $20.80 \mathrm{a}( \pm 2.78)$ & $20.21 \mathrm{a}( \pm 2.70)$ \\
\hline$p$-Coumaric acid & $1.33 \mathrm{a}( \pm 0.51)$ & $1.18 \mathrm{~b}( \pm 0.31)$ & $2.01 \mathrm{a}( \pm 0.56)$ & $2.04 \mathrm{a}( \pm 0.42)$ \\
\hline Total phenolic acids ${ }^{\mathrm{e}}$ & 227.82 a $( \pm 44.72)$ & $187.41 \mathrm{~b}( \pm 22.00)$ & $214.27 \mathrm{~b}( \pm 28.73)$ & $243.92 \mathrm{a}( \pm 32.87)$ \\
\hline \multicolumn{5}{|l|}{ Flavan-3-ols } \\
\hline (+)-Catechin & $12.21 \mathrm{a}( \pm 0.99)$ & $9.19 \mathrm{~b}( \pm 0.53)$ & $10.29 \mathrm{a}( \pm 0.54)$ & $10.07 \mathrm{a}( \pm 0.70)$ \\
\hline Procyanidin B1 & $19.45 \mathrm{a}( \pm 1.59)$ & $16.20 \mathrm{~b}( \pm 1.54)$ & $17.26 \mathrm{a}( \pm 1.50)$ & $16.81 \mathrm{a}( \pm 1.34)$ \\
\hline Non-coloured polymers ${ }^{j}$ & $213.01 \mathrm{a}( \pm 43.05)$ & $178.04 \mathrm{~b}( \pm 23.90)$ & 174.30 a $( \pm 28.57)$ & 178.89 a $( \pm 28.59)$ \\
\hline Total monomers ${ }^{\mathrm{k}}$ & 669.86 a $( \pm 79.28)$ & $584.17 \mathrm{~b}( \pm 42.63)$ & $535.33 \mathrm{~b}( \pm 39.96)$ & $587.23 \mathrm{a}( \pm 43.15)$ \\
\hline
\end{tabular}

${ }^{\mathrm{a}} \mathrm{mg} / \mathrm{L}$ unless otherwise noted and means taken over all treatments for a specific vintage; ${ }^{\mathrm{b}}$ different letters in a row pertaining to a specific trial denote significant differences $(\mathrm{P}<0.05) ;{ }^{\mathrm{c}}$ standard deviation; ${ }^{\mathrm{d}} \mathrm{mg}$ corresponding anthocyanin-3-Glc equivalents/L; ${ }^{\mathrm{e}}$ sum of phenolic group content; ${ }^{\mathrm{f}}$ mg malvidin-3-Glc equivalents/L; ${ }^{\mathrm{g}}$ mg rutin equivalents/L; ${ }^{\mathrm{h}}$ data not shown due to large number of wines without detectable amounts of compound; ${ }^{\mathrm{i}} \mathrm{mg} p$-coumaric acid equivalents/L; ${ }^{\mathrm{j}}$ mg (+)-catechin equivalents/L; ${ }^{\mathrm{k}}$ sum of all quantified monomeric phenolic compounds; Dp = delphinidin; Glc = glucoside; Glc-Ac = acetylglucoside; Glc-Coum = $p$-coumaroylglucoside; $\mathrm{Pt}=$ petunidin $\mathrm{Pn}=$ peonidin $; \mathrm{Mv}=$ malvidin $; \mathrm{Q}=$ quercetin $;$ rham $=$ rhamnoside .

(juice/skin mixing trial). Similarly, the caffeoyltartaric (caftaric) acid, total phenolic acid and total monomer contents were 18, 18 and $13 \%$ lower in the 2001 wines (juice/skin mixing trial). Only a few of the 2002 wines from the pre-fermentation maceration trial contained kaempferol compared to the 2001 wines which all had measurable concentrations. All the 2002 wines from the juice/skin mixing trial contained kaempferol, but its content was less than that of the 2001 wines. Isorhamnetin was only detected in the 2002 wines from the juice/skin mixing trial. The phenolic acids, caffeic acid, $p$-coumaroyltartaric (coutaric) acid and $p$ coumaric acid, flavan-3-ols, and polymers were not affected by vintage in the juice/skin mixing trial.
The $\mathrm{TAC}_{\mathrm{M}}$ of the 2001 and 2002 wines from the pre-fermentation trial was 15 and $12 \%$ higher, respectively, than that of the 2000 wines (Table 1). The $\mathrm{TAC}_{\mathrm{CAL}}$ was $10 \%$ lower for the 2002 wines compared to the 2001 wines (pre-fermentation maceration trial), while the $\mathrm{TAC}_{\mathrm{R}}$ showed no significant differences. In the juice/skin mixing trial, the $\mathrm{TAC}_{\mathrm{M}}, \mathrm{TAC}_{\mathrm{CAL}}$ and $\mathrm{TAC}_{\mathrm{R}}$ of the 2002 wines had 7,11 and 7\% higher values, respectively, compared to those of the 2001 wines.

All objective colour parameters had markedly higher values for the 2002 wines of the pre-fermentation maceration trial, with $C^{*}$, $h^{*}, L^{*}, a^{*}$ and $b^{*}$ values $37,74,27,27$ and $130 \%$ higher, respectively, than the values for the 2000 wines (Table 1). The lowest 
$h^{*}, L^{*}$ and $b^{*}$ values were observed for the 2001 wines, while the 2000 wines had the lowest $C^{*}$ and $a^{*}$ values in this trial. In the juice/skin mixing trial, the 2000 wines also had the lowest $C^{*}$ and $a^{*}$ values, but the highest $h^{*}$ and $b^{*}$ values. The lowest $h^{*}$ and $b^{*}$ values were observed for the 2002 wines, while the 2001 wines had the highest $C^{*}$ and $a^{*}$ values. Similar to the wines of the prefermentation trial, the 2001 wines had lower $L^{*}$ values compared to the 2000 and 2002 wines.

Pre-fermentation maceration: effect on phenolic composition

Only the treatments that either significantly increased or decreased the phenolic content of the Pinotage wines compared to the control are discussed. The $10^{\circ} \mathrm{C} / 2$ days treatment in 2000 $(16 \%)$ and the $15^{\circ} \mathrm{C} / 2$ days treatment in 2001 (9\%) resulted in wines with increased total phenol content (Fig. 1). The same treatments also increased the total flavan-3-ol (DAC) content of the wine by 17 and $11 \%$, respectively. The (+)-catechin content of the 2001 wines was increased by the $15^{\circ} \mathrm{C} / 2$ days treatment (19\%) (Fig. 2). On the other hand, the $10^{\circ} \mathrm{C} / 4$ days $(13 \%)$ and $15^{\circ} \mathrm{C} / 1$ day $(10 \%)$ treatments decreased the total flavan-3-ol content (DAC) of the 2001 wines (Fig. 1). In 2002, the (+)-catechin and procyanidin $\mathrm{B} 1$ contents were decreased by 12 and $18 \%$, respectively, for the $15^{\circ} \mathrm{C} / 1$ day treatment (Fig. 2), but the total flavan-3-ol content (DAC) (Fig. 1) was not affected by any of the treatments. Treatments also had little effect on the non-coloured polymer content of the wine (Fig. 2). Only the $10^{\circ} \mathrm{C} / 4$ days treatment in 2002 resulted in wines with a $24 \%$ higher non-coloured polymer content relative to that of the control wine. Furthermore, pre-fermentation treatments also did not affect the individual flavonol content of the wines (data not shown), except for the $15^{\circ} \mathrm{C} / 4$ days treatment in 2001 resulting in wines with a $23 \%$ higher unknown flavonol content than the control wines (Fig. 3).

The monomeric and total anthocyanin contents ( $\mathrm{pH}$ shift), as well as peonidin-3-Glc, peonidin-3-Glc-Ac and coloured polymer (HPLC) contents, of the wines were not significantly affected by any of the treatments, irrespective of vintage (data not shown). Concerning individual anthocyanins, the delphinidin-3-Glc-Ac and vitisin A contents of the wine were increased by pre-fermentation maceration treatments. The $15^{\circ} \mathrm{C} / 1$ day $(18 \%)$ and $15^{\circ} \mathrm{C} / 2$ days (20\%) treatments increased the delphinidin-3-GlcAc content of the 2001 wines (Fig. 3). The vitisin A content of the 2001 wines was increased between 49 and $101 \%$ by all the treatments, except for the $10^{\circ} \mathrm{C} / 4$ days treatment, which had no effect. However, in 2002 only the $10^{\circ} \mathrm{C} / 4$ days treatment (46\%), as well as the $15^{\circ} \mathrm{C} / 2$ days treatment $(50 \%)$, increased the vitisin A content of the wines.

In 2001, the individual phenolic acid contents were significantly increased by the pre-fermentation maceration treatments, especially when using the higher temperature. Substantial increases were obtained for caftaric, coutaric and $p$-coumaric acid contents, and thus the total phenolic acid content (increased between 9 and $69 \%$ ) (Fig. 2). However, the opposite trend was observed for the 2002 wines, namely a decrease in total phenolic acid content between 9 and 29\%. The caffeic acid content of the 2001 wines was affected by the $10^{\circ} \mathrm{C} / 1$ day $(33 \%)$ and $15^{\circ} \mathrm{C} / 1$ day $(33.6 \%)$ treatments, giving higher and lower values than that of the control, respectively, while no significant differences were observed for the 2002 wines. Considering gallic acid, the $10^{\circ} \mathrm{C} / 1$ day treatment $(20 \%)$ in 2001 and the $10^{\circ} \mathrm{C} / 4$ days $(16 \%)$ and $15^{\circ} \mathrm{C} / 4$ days

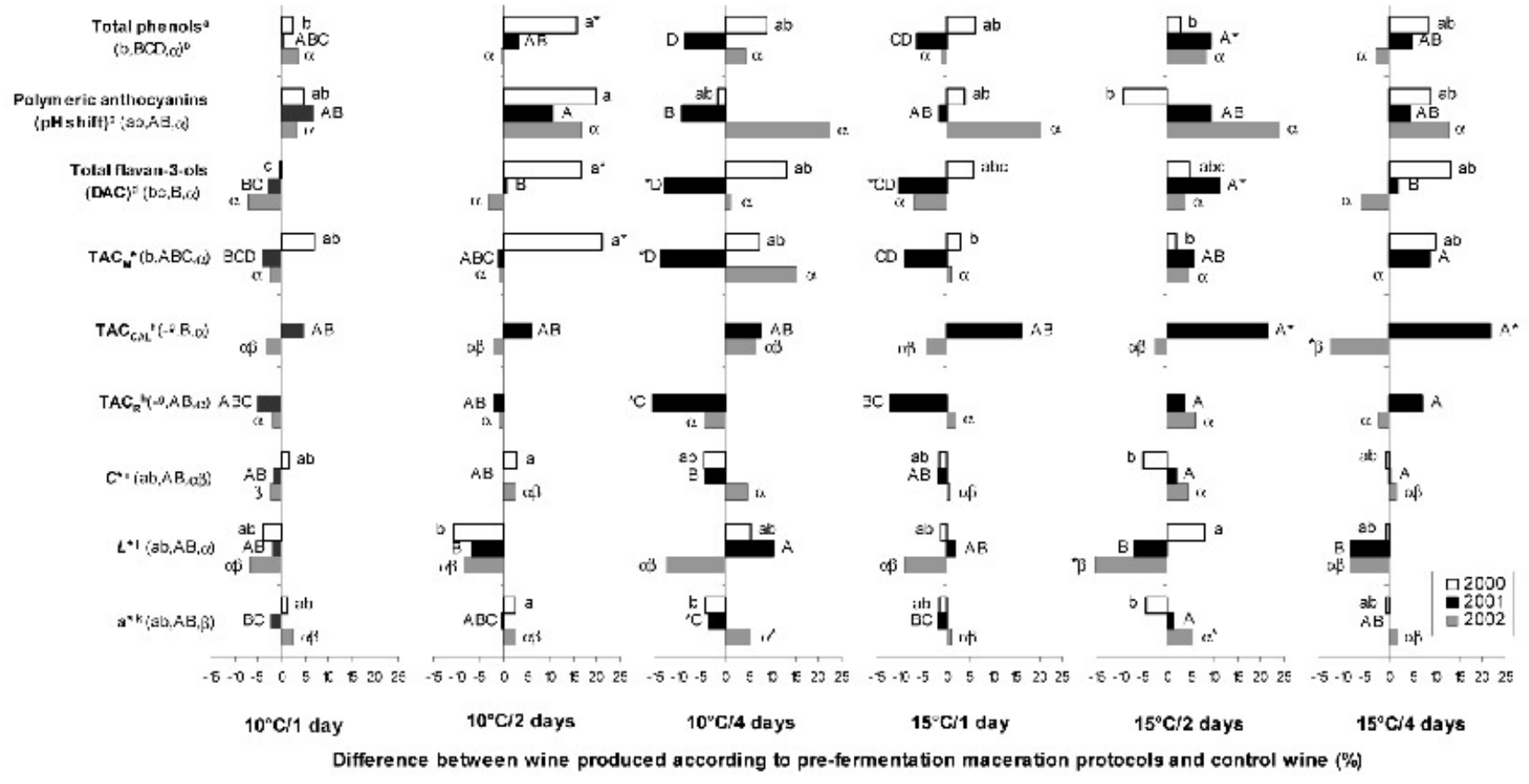

FIGURE 1

The percentage differences in phenolic content as measured spectrophotometrically, total antioxidant capacity and objective colour between the 2000,2001 and 2002 Pinotage wines produced according to different pre-fermentation maceration protocols compared to the control wine $\left[{ }^{\mathrm{a}}\right.$ measured using the Folin-Ciocalteau assay; ${ }^{\mathrm{b}}$ different lowercase Roman (2000), uppercase Roman (2001) and Greek (2002) alphabet letters on the bars for the 2000, 2001 and 2002 wines and the control indicated next to the parameter name denote significant differences $(\mathrm{P}<0.05) ;{ }^{\mathrm{c}}$ measured using the $\mathrm{pH}$ shift assay; ${ }^{\mathrm{d}}$ measured using the DAC assay; ${ }^{\mathrm{e}}$ total antioxidant capacity in mM Trolox equivalents; ${ }^{\mathrm{f}}$ total antioxidant capacity in $\mathrm{mM}$ Trolox equivalents as calculated from the content of monomeric phenolic compounds and their Trolox equivalent antioxidant capacity; ${ }^{\mathrm{g}}$ no values for the 2000 wines; ${ }^{\mathrm{h}} \mathrm{TAC}_{\mathrm{R}}=\mathrm{TAC}_{\mathrm{M}}-\mathrm{TAC} \mathrm{CAL}_{\mathrm{L}} ;{ }^{\mathrm{i}}$ chroma; ${ }^{\mathrm{j}}$ lightness; ${ }^{\mathrm{k}}$ red/green chromaticity; $*$ indicate significant $(\mathrm{P}<0.05)$ differences from control wines]. 


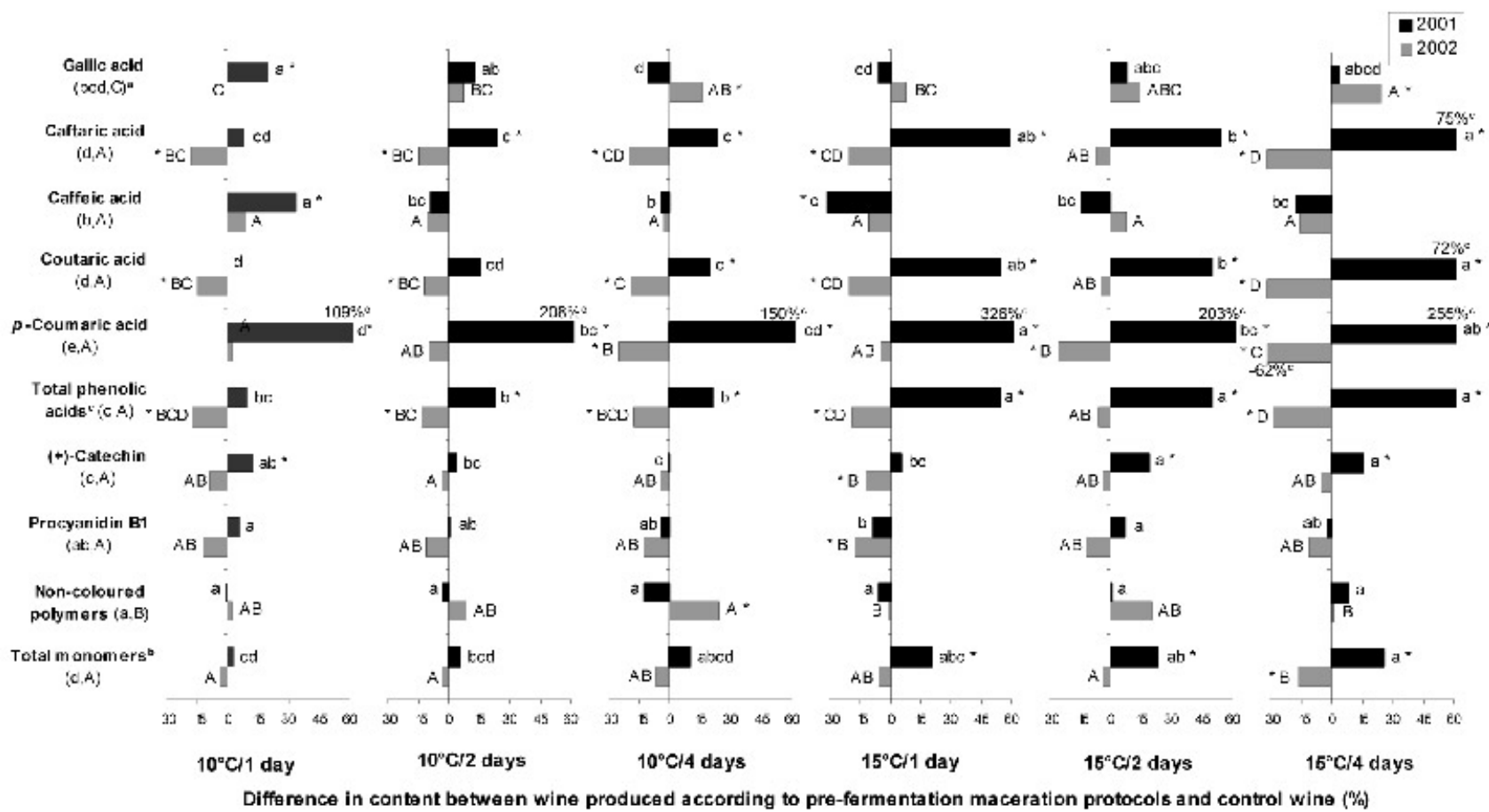

FIGURE 2

The percentage differences in phenolic acid, flavan-3-ol, non-coloured polymer and total monomer contents between the 2001 and 2002 Pinotage wines produced according to different pre-fermentation maceration protocols and the control wine [ ${ }^{a}$ different lowercase (2001) and uppercase (2002) letters on the bars for the 2001 and 2002 wines and the control indicated next to the parameter name denote significant differences $(\mathrm{P}<0.05) ;{ }^{\mathrm{b}}$ sum of phenolic group content; ${ }^{\mathrm{c}}$ values exceed the scale; $*$ indicate significant $(\mathrm{P}<0.05)$ differences from control wines].

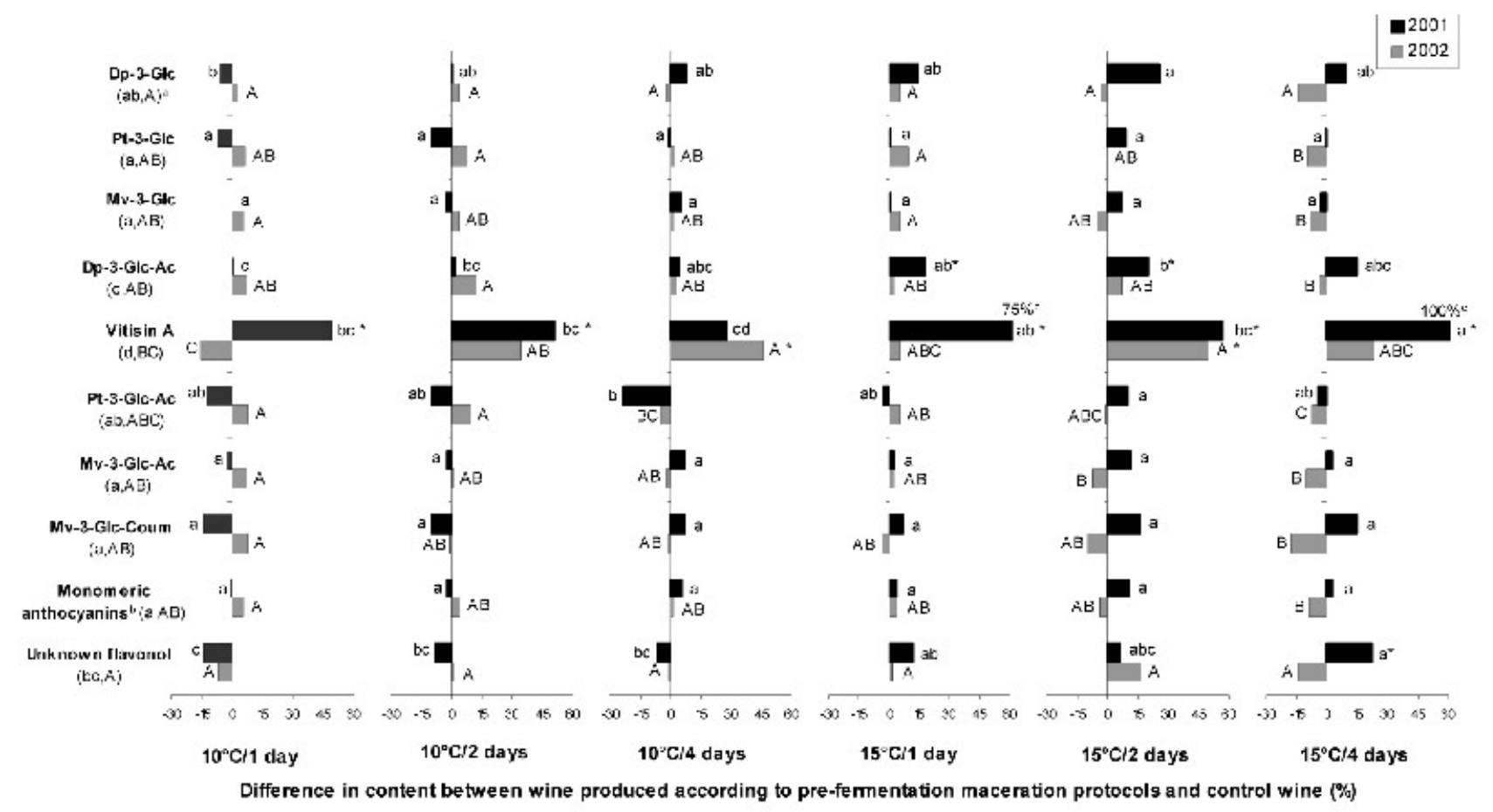

FIGURE 3

The percentage differences in monomeric anthocyanin and flavonol contents between the 2001 and 2002 Pinotage wines produced according to different pre-fermentation maceration protocols and the control wine [ ${ }^{\mathrm{a}}$ different lowercase (2001) and uppercase (2002) letters on the bars for the 2001 and 2002 wines and the control indicated next to the parameter name denote significant differences $(\mathrm{P}<0.05) ;{ }^{\mathrm{b}}$ sum of phenolic group content; ${ }^{\mathrm{c}}$ values exceed the scale; $*$ indicate significant $(\mathrm{P}<0.05)$ differences from control wines; $\mathrm{Dp}=$ delphinidin $;$ Glc $=$ glucoside $;$ Glc-Ac $=$ acetylglucoside $;$ Glc-Coum $=p$-coumaroylglucoside $; \mathrm{Pt}=$ petunidin $;$ Pn $=$ peonidin; $\mathrm{Mv}=$ malvidin $]$. 
(24\%) treatments in 2002 resulted in wines with higher contents than the control.

The total monomer content (HPLC) of the 2001 wines treated at $15^{\circ} \mathrm{C}$ was between 20 and $26 \%$ higher than that of the control wines (Fig. 2). In 2002, the pre-fermentation maceration treatments had no effect, except for the $15^{\circ} \mathrm{C} / 4$ days treatment which gave wines with $16 \%$ lower total monomer contents (HPLC) than the control.

\section{Pre-fermentation maceration: effect on antioxidant capacity}

The effect of pre-fermentation maceration treatments on $\mathrm{TAC}_{\mathrm{M}}$ was only significant for the $10^{\circ} \mathrm{C} / 2$ days treatment in 2000 (Fig. 1). This treatment gave wines with $21 \%$ higher $\mathrm{TAC}_{\mathrm{M}}$ values than the control. In 2001 and 2002, the pre-fermentation maceration treatments had no effect on the $\mathrm{TAC}_{\mathrm{M}}$ of the wines. Taking the individual phenolic content into account, the $\mathrm{TAC}_{\mathrm{CAL}}$ values of the 2001 wines, produced according to the $15^{\circ} \mathrm{C} / 2$ days and $15^{\circ} \mathrm{C} / 4$ days protocols, were $21 \%$ higher than that of the control, but the $15^{\circ} \mathrm{C} / 4$ days treatment gave a $12 \%$ lower $\mathrm{TAC}_{\mathrm{CAL}}$ value than the control wine in 2002. In both 2001 and 2002, the pre-fermentation maceration treatments did not result in any difference between the wines in terms of $\mathrm{TAC}_{\mathrm{R}}$ compared to that of the control. The contribution of different phenolic groups to the $\mathrm{TAC}_{\mathrm{CAL}}$ of the 2001 and 2002 wines is depicted in Figs 4 and 5. Both the flavan-3-ols and flavonols had a small contribution to the $\mathrm{TAC}_{\mathrm{CAL}}$, and none of the treatments increased the contribution of these phenolic groups relative to that of the control. The $15^{\circ} \mathrm{C} / 1$ day treatment decreased the contribution of flavan-3-ols to the $\mathrm{TAC}_{\mathrm{CAL}}$ of the 2002 wines in comparison to the control. In 2001, several of the treatments, most notably the treatments at $15^{\circ} \mathrm{C}$, increased the contribution of total phenolic acids to the $\mathrm{TAC}_{\mathrm{CAL}}$. In 2002 , the $10^{\circ} \mathrm{C} / 1$ day, $15^{\circ} \mathrm{C} / 1$ day and $15^{\circ} \mathrm{C} / 4$ days treatments decreased the contribution of phenolic acids to $\mathrm{TAC}_{\mathrm{CAL}}$, compared to that of the control wines.

\section{Pre-fermentation Maceration: Effect on Objective Colour Parameters}

Variation in objective colour parameters between vintages was large, similar to the results for phenolic composition and antioxidant capacity. Pre-fermentation maceration did not significantly affect the objective colour parameters of the 2000 wines com-

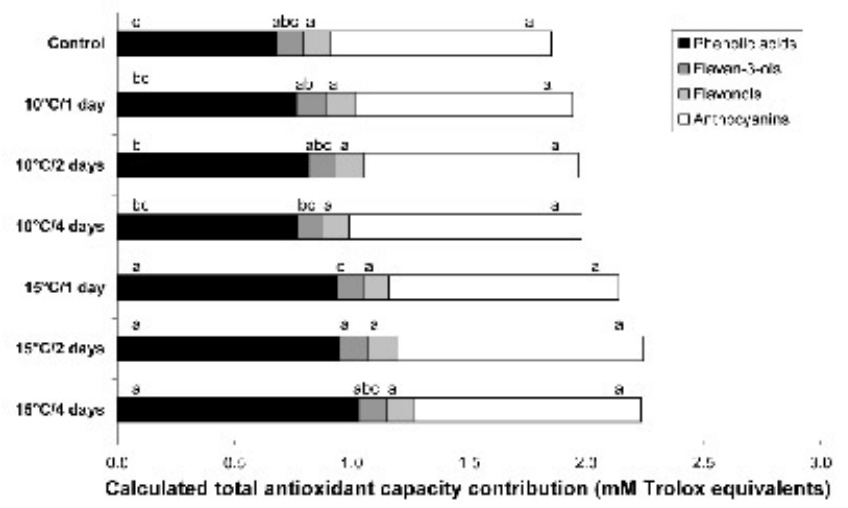

FIGURE 4

Calculated total antioxidant capacity contributions of phenolic groups for the 2001 Pinotage wines produced according to different pre-fermentation maceration protocols [different letters for the contribution of a specific phenolic group denote significant differences $(\mathrm{P}<0.05)]$. pared to that of the control wines (Fig. 1). Furthermore, the prefermentation maceration treatments had no effect on the $h^{*}$ or $b^{*}$ values of wines of any of the vintages (data not shown). The $10^{\circ} \mathrm{C} / 4$ days treatment lowered the $a^{*}$ value of the 2001 wines by $4 \%$, compared to the control wines. However, in 2002, the same treatment increased the $a^{*}$ value by $5 \%$. The only other treatment that had a significant effect on the objective colour parameters, was the $15^{\circ} \mathrm{C} / 2$ days treatment of 2002 , which lowered $L^{*}$ by $15 \%$ and increased $a^{*}$ by $5 \%$.

\section{Juice/Skin mixing during maceration: effect on phenolic com- position}

Considering the juice/skin mixing techniques used during maceration, the pumping-over action in general was less effective in extracting phenolic compounds than the punching-down and rotor actions (see Tables 3-5). The latter treatments gave wines with similar phenolic content. These trends were most notable for the 2000 and 2002 wines. Only significant differences will be discussed. In 2000, the pumping-over treatment resulted in wines with lower total phenol (12\%), polymeric anthocyanin ( $\mathrm{pH}$ shift) (24\%) and flavan-3-ol (12\%) contents than when punching-down mixing were used (see Table 3). The rotor treatment gave wines with $10 \%$ higher flavan-3-ol content (DAC) than the punchingdown treatment. According to spectrophotometric data, mixing treatment had no effect on the phenolic content of the 2001 wines. In 2002, the pumping-over treatment gave wines with lower total phenol (10\%) and flavan-3-ol (DAC) (16\%) contents, as well as monomeric $(12 \%)$, polymeric $(26 \%)$ and total anthocyanin $(14 \%)$ contents ( $\mathrm{pH}$ shift), than the punching-down treatments.

None of the individual anthocyanin and coloured polymer (HPLC) contents of the 2001 wines were affected by mixing technique. Furthermore, no differences in delphinidin-3-Glc, petunidin3-Glc, peonidin-3-Glc, delphinidin-3-Glc-Ac and petunidin-3-GlcAc contents were observed for the 2002 wines (data not shown). The mixing techniques did, however, affect the remaining individual anthocyanin and the coloured polymer (HPLC) contents of the 2002 wines, with pumping-over giving between 7 and $31 \%$ lower values than the punching-down rotor treatments (Table 4).

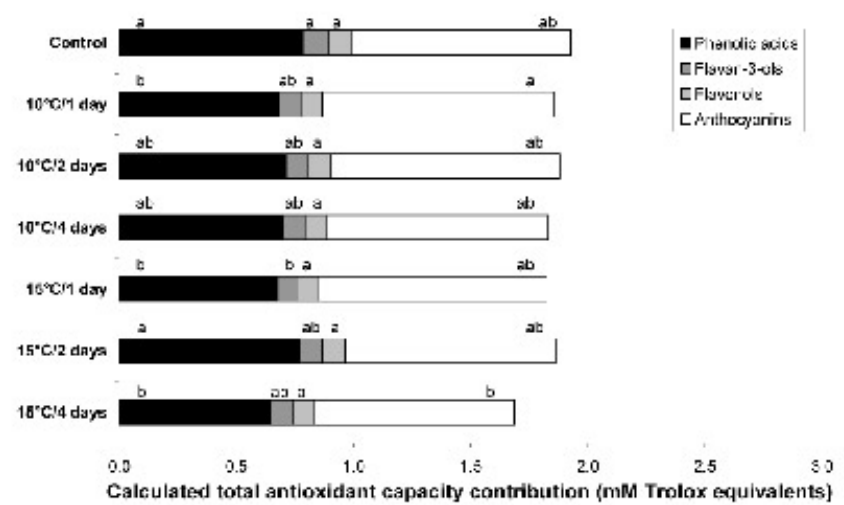

FIGURE 5

Calculated total antioxidant capacity contributions of phenolic groups for the 2002 Pinotage wines produced according to different pre-fermentation maceration protocols [different letters for the contribution of a specific phenolic group denote significant differences $(\mathrm{P}<0.05)]$. 
TABLE 3

Phenolic composition (measured spectrophotometrically) of the 2000, 2001 and 2002 Pinotage wines produced according to different juice/skin mixing protocols and mixing frequencies.

\begin{tabular}{|c|c|c|c|c|c|c|}
\hline Year & $\begin{array}{l}\text { Treatment/ } \\
\text { Frequency }\end{array}$ & $\begin{array}{c}\text { Total } \\
\text { phenols }^{\mathrm{a}}\end{array}$ & $\begin{array}{c}\text { Monomeric } \\
\text { anthocyanins }^{b}\end{array}$ & $\begin{array}{c}\text { Polymeric } \\
\text { anthocyanins }^{b}\end{array}$ & $\begin{array}{c}\text { Total } \\
\text { anthocyanins }^{b}\end{array}$ & $\begin{array}{c}\text { Total } \\
\text { flavan-3-ols }\end{array}$ \\
\hline \multirow[t]{3}{*}{2000} & Punching-down & $2109.7 \mathrm{a}^{\mathrm{d}}( \pm 140.5)^{\mathrm{e}}$ & $192.0 \mathrm{a}( \pm 15.3)$ & $( \pm 5.6)$ & 274.0 a $( \pm 22.9)$ & $159.4 \mathrm{~b}( \pm 12.4)$ \\
\hline & Pumping-over & $1851.4 \mathrm{~b}( \pm 79.7)$ & $173.9 \mathrm{a}( \pm 18.0)$ & $( \pm 7.0)$ & $236.1 \mathrm{~b}( \pm 23.9)$ & $140.6 \mathrm{c} \quad( \pm 9.9)$ \\
\hline & Rotor & 2207.8 a $( \pm 152.2)$ & $189.3 \mathrm{a}( \pm 18.7)$ & $73.8 \mathrm{a} \quad( \pm 7.3)$ & $263.1 \mathrm{ab}( \pm 24.9)$ & 175.9 a $( \pm 21.8)$ \\
\hline \multirow[t]{3}{*}{2001} & Punching-down & $2774.1 \mathrm{a}( \pm 119.2)$ & 354.8 a $( \pm 29.0)$ & $100.3 \mathrm{a}( \pm 11.3)$ & 455.2 a $( \pm 38.9)$ & $211.5 \mathrm{a}( \pm 14.7)$ \\
\hline & Pumping-over & 2681.7 a $( \pm 210.6)$ & $334.0 \mathrm{a}( \pm 12.4)$ & $91.8 \mathrm{a} \quad( \pm 11.7)$ & 425.8 a $( \pm 20.3)$ & $210.1 \mathrm{a}( \pm 21.3)$ \\
\hline & Rotor & $2640.4 \mathrm{a}( \pm 74.7)$ & $347.7 \mathrm{a}( \pm 18.7)$ & $99.9 \mathrm{a} \quad( \pm 8.1)$ & 447.6 a $( \pm 21.6)$ & $199.4 \mathrm{a} \quad( \pm 5.6)$ \\
\hline \multirow[t]{3}{*}{2002} & Punching-down & $2154.4 \mathrm{a}( \pm 163.4)$ & 383.0 a $( \pm 26.5)$ & $( \pm 9.2)$ & 432.6 a $( \pm 28.6)$ & 177.5 a $( \pm 11.6)$ \\
\hline & Pumping-over & $1931.9 \mathrm{~b}( \pm 131.00)$ & $336.3 \mathrm{~b}( \pm 43.1)$ & $( \pm 6.5)$ & $373.1 \mathrm{~b}( \pm 49.4)$ & $149.8 \mathrm{~b} \quad( \pm 9.9)$ \\
\hline & Rotor & $2253.7 \mathrm{a}( \pm 102.2)$ & 386.6 a $( \pm 15.4)$ & $( \pm 2.5)$ & $432.5 \mathrm{a}( \pm 15.6)$ & $183.1 \mathrm{a}( \pm 13.3)$ \\
\hline \multirow[t]{2}{*}{2000} & Every hour & 2066.8 a $( \pm 181.1)$ & $186.1 \mathrm{a}( \pm 19.7)$ & $72.3 \mathrm{a} \quad( \pm 10.0)$ & 258.4 a $( \pm 28.7)$ & 158.9 a $( \pm 25.9)$ \\
\hline & Every 3 hours & 2045.8 a $( \pm 220.5)$ & 184.0 a $( \pm 17.9)$ & $73.0 \mathrm{a} \quad( \pm 12.6)$ & $257.0 \mathrm{a}( \pm 28.5)$ & $158.4 \mathrm{a}( \pm 15.9)$ \\
\hline \multirow[t]{2}{*}{2001} & Every hour & 2698.0 a $( \pm 195.7)$ & $336.5 \mathrm{a}( \pm 19.2)$ & $97.1 \mathrm{a} \quad( \pm 8.4)$ & $433.7 \mathrm{a}( \pm 25.4)$ & $203.4 \mathrm{a}( \pm 12.7)$ \\
\hline & Every 3 hours & 2699.4 a ( \pm 93.9$)$ & $354.5 \mathrm{a}( \pm 21.4)$ & $97.6 \mathrm{a} \quad( \pm 13.0)$ & $452.0 \mathrm{a}( \pm 31.8)$ & 210.6 a $( \pm 17.7)$ \\
\hline \multirow[t]{2}{*}{2002} & Every hour & 2174.7 a $( \pm 182.0)$ & 375.7 a $( \pm 24.9)$ & $47.9 \mathrm{a} \quad( \pm 8.7)$ & $423.5 \mathrm{a}( \pm 30.4)$ & $176.3 \mathrm{a}( \pm 18.4)$ \\
\hline & Every 3 hours & 2051.9 a $( \pm 181.8)$ & 361.6 a $( \pm 46.9)$ & $( \pm 6.5)$ & 402.0 a $( \pm 52.6)$ & $164.0 \mathrm{~b}( \pm 17.6)$ \\
\hline
\end{tabular}

${ }^{\mathrm{a}} \mathrm{mg}$ gallic acid equivalents/L; ${ }^{\mathrm{b}} \mathrm{mg}$ malvidin-3-glucoside equivalents/L; ${ }^{\mathrm{c}} \mathrm{mg}(+)$-catechin equivalents/L; ${ }^{\mathrm{d}}$ different letters within a group in a column denote significant differences $(\mathrm{P}<0.05) ;{ }^{\mathrm{e}}$ standard deviation.

TABLE 4

Anthocyanin and flavonol contents of the 2001 and 2002 Pinotage wines produced according to different juice/skin mixing protocols and mixing frequencies.

\begin{tabular}{|c|c|c|c|c|c|c|c|c|c|c|c|c|c|c|}
\hline \multirow{2}{*}{ Year } & \multirow{2}{*}{$\begin{array}{l}\text { Treatment/ } \\
\text { Frequency }\end{array}$} & \multicolumn{6}{|c|}{ Monomeric anthocyanins } & \multirow{2}{*}{$\begin{array}{l}\text { Coloured } \\
\text { polymers }\end{array}$} & \multicolumn{6}{|c|}{ Flavonols } \\
\hline & & Mv-3-Glc & $\begin{array}{c}\text { Vitisin } \\
\mathbf{A}^{\mathbf{b}}\end{array}$ & $\begin{array}{c}\text { Pn-3- } \\
\text { Glc-Ac }\end{array}$ & $\begin{array}{l}\text { Mv-3- } \\
\text { Glc-Ac }\end{array}$ & $\begin{array}{l}\text { Mv-3-Glc- } \\
\text { Coumb }^{b}\end{array}$ & Total $^{c}$ & & Unknown $^{\mathrm{e}}$ & Q-3-Glc & $\begin{array}{c}\text { Q-3- } \\
\text { Rham }\end{array}$ & $\begin{array}{l}\text { Querce- } \\
\text { tin }\end{array}$ & $\begin{array}{c}\text { Kaemp- } \\
\text { ferol }\end{array}$ & Total $^{c}$ \\
\hline \multirow[t]{3}{*}{2001} & Punching-down & $\begin{array}{l}152.07 \mathrm{a}^{\mathrm{f}} \\
( \pm 14.30)^{\mathrm{g}}\end{array}$ & $\begin{array}{c}8.79 \mathrm{a} \\
( \pm 1.57)\end{array}$ & $\begin{array}{c}3.16 \mathrm{a} \\
( \pm 0.34)\end{array}$ & $\begin{array}{l}49.99 \mathrm{a} \\
( \pm 4.17)\end{array}$ & $\begin{array}{l}20.16 \mathrm{a} \\
( \pm 1.91)\end{array}$ & $\begin{array}{l}260.40 \mathrm{a} \\
( \pm 25.75)\end{array}$ & $\begin{array}{c}7.19 \mathrm{a} \\
( \pm 2.41)\end{array}$ & $\begin{array}{l}18.90 \mathrm{a} \\
( \pm 2.18)\end{array}$ & $\begin{array}{l}16.22 \mathrm{a} \\
( \pm 2.25)\end{array}$ & $\begin{array}{l}10.48 \mathrm{a} \\
( \pm 1.25)\end{array}$ & $\begin{array}{c}1.99 \mathrm{a} \\
( \pm 0.29)\end{array}$ & $\begin{array}{l}0.52 \mathrm{ab} \\
( \pm 0.08)\end{array}$ & $\begin{array}{l}48.11 \mathrm{a} \\
( \pm 5.18)\end{array}$ \\
\hline & Pumping-over & $\begin{array}{l}145.95 \mathrm{a} \\
( \pm 23.57)\end{array}$ & $\begin{array}{c}7.89 \mathrm{a} \\
( \pm 3.98)\end{array}$ & $\begin{array}{c}2.89 a \\
( \pm 0.24)\end{array}$ & $\begin{array}{l}46.49 \mathrm{a} \\
( \pm 6.61)\end{array}$ & $\begin{array}{l}20.41 \mathrm{a} \\
( \pm 4.32)\end{array}$ & $\begin{array}{l}247.68 \mathrm{a} \\
( \pm 31.65)\end{array}$ & $\begin{array}{c}6.83 \mathrm{a} \\
( \pm 2.99)\end{array}$ & $\begin{array}{r}16.94 \mathrm{a} \\
( \pm 2.74)\end{array}$ & $\begin{array}{l}16.19 \mathrm{a} \\
( \pm 1.97)\end{array}$ & $\begin{array}{l}10.22 \mathrm{a} \\
( \pm 0.91)\end{array}$ & $\begin{array}{c}1.95 \mathrm{a} \\
( \pm 0.24)\end{array}$ & $\begin{array}{c}0.54 \mathrm{a} \\
( \pm 0.04)\end{array}$ & $\begin{array}{l}45.83 \mathrm{a} \\
( \pm 5.51)\end{array}$ \\
\hline & Rotor & $\begin{array}{l}138.46 \mathrm{a} \\
( \pm 16.82)\end{array}$ & $\begin{array}{c}9.83 \mathrm{a} \\
( \pm 3.67)\end{array}$ & $\begin{array}{c}2.84 \mathrm{a} \\
( \pm 0.27)\end{array}$ & $\begin{array}{l}44.74 \mathrm{a} \\
( \pm 6.30)\end{array}$ & $\begin{array}{l}17.44 \mathrm{a} \\
( \pm 2.71)\end{array}$ & $\begin{array}{l}236.11 \mathrm{a} \\
( \pm 25.55)\end{array}$ & $\begin{array}{c}6.34 \mathrm{a} \\
( \pm 1.41)\end{array}$ & $\begin{array}{r}16.71 \mathrm{a} \\
( \pm 1.59)\end{array}$ & $\begin{array}{l}14.23 \mathrm{a} \\
( \pm 2.01)\end{array}$ & $\begin{array}{c}9.46 \mathrm{a} \\
( \pm 1.48)\end{array}$ & $\begin{array}{c}1.57 \mathrm{~b} \\
( \pm 0.29)\end{array}$ & $\begin{array}{c}0.43 \mathrm{~b} \\
( \pm 0.10)\end{array}$ & $\begin{array}{l}42.41 \mathrm{a} \\
( \pm 5.16)\end{array}$ \\
\hline \multirow[t]{3}{*}{2002} & Punching-down & $\begin{array}{l}181.10 \mathrm{a} \\
( \pm 20.24)\end{array}$ & $\begin{array}{c}6.39 \mathrm{a} \\
( \pm 1.58)\end{array}$ & $\begin{array}{c}3.87 \mathrm{a} \\
( \pm 0.48)\end{array}$ & $\begin{array}{l}53.09 \mathrm{a} \\
( \pm 6.07)\end{array}$ & $\begin{array}{c}24.93 \mathrm{ab} \\
( \pm 5.37)\end{array}$ & $\begin{array}{l}299.12 \mathrm{a} \\
( \pm 34.43)\end{array}$ & $\begin{array}{c}9.08 \mathrm{a} \\
( \pm 2.06)\end{array}$ & $\begin{array}{r}10.14 \mathrm{a} \\
( \pm 1.02)\end{array}$ & $\begin{array}{c}8.07 \mathrm{a} \\
( \pm 0.41)\end{array}$ & $\begin{array}{c}9.41 \mathrm{a} \\
( \pm 0.56)\end{array}$ & $\begin{array}{l}3.08 \mathrm{ab} \\
( \pm 0.84)\end{array}$ & $\begin{array}{l}0.23 \mathrm{ab} \\
( \pm 0.10)\end{array}$ & $\begin{array}{l}31.33 \mathrm{a} \\
( \pm 2.14)\end{array}$ \\
\hline & Pumping-over & $\begin{array}{l}162.53 \mathrm{~b} \\
( \pm 16.27)\end{array}$ & $\begin{array}{c}4.41 \mathrm{~b} \\
( \pm 1.42)\end{array}$ & $\begin{array}{c}3.40 \mathrm{~b} \\
( \pm 0.44)\end{array}$ & $\begin{array}{l}47.75 b \\
( \pm 3.13)\end{array}$ & $\begin{array}{l}23.13 b \\
( \pm 1.87)\end{array}$ & $\begin{array}{l}269.59 \mathrm{a} \\
( \pm 26.15)\end{array}$ & $\begin{array}{c}7.08 \mathrm{~b} \\
( \pm 0.90)\end{array}$ & $\begin{array}{c}7.95 \mathrm{~b} \\
( \pm 2.52)\end{array}$ & $\begin{array}{c}6.54 \mathrm{~b} \\
( \pm 0.93)\end{array}$ & $\begin{array}{c}7.98 \mathrm{~b} \\
( \pm 0.78)\end{array}$ & $\begin{array}{c}2.41 \mathrm{~b} \\
( \pm 0.87)\end{array}$ & $\begin{array}{c}0.11 b \\
( \pm 0.13)\end{array}$ & $\begin{array}{l}25.14 \mathrm{~b} \\
( \pm 4.35)\end{array}$ \\
\hline & Rotor & $\begin{array}{c}170.62 \mathrm{ab} \\
( \pm 5.73)\end{array}$ & $\begin{array}{c}7.27 \mathrm{a} \\
( \pm 0.89)\end{array}$ & $\begin{array}{l}3.51 \mathrm{ab} \\
( \pm 0.10)\end{array}$ & $\begin{array}{l}52.78 \mathrm{a} \\
( \pm 2.30)\end{array}$ & $\begin{array}{l}26.55 \mathrm{a} \\
( \pm 1.60)\end{array}$ & $\begin{array}{l}291.95 \mathrm{a} \\
( \pm 9.40)\end{array}$ & $\begin{array}{l}7.77 \mathrm{ab} \\
( \pm 1.71)\end{array}$ & $\begin{array}{r}11.24 \mathrm{a} \\
( \pm 1.66)\end{array}$ & $\begin{array}{c}7.91 \mathrm{a} \\
( \pm 0.71)\end{array}$ & $\begin{array}{c}8.71 \mathrm{a} \\
( \pm 0.94)\end{array}$ & $\begin{array}{c}3.65 \mathrm{a} \\
( \pm 0.58)\end{array}$ & $\begin{array}{c}0.34 \mathrm{a} \\
( \pm 0.10)\end{array}$ & $\begin{array}{l}32.21 \mathrm{a} \\
( \pm 3.80)\end{array}$ \\
\hline \multirow[t]{2}{*}{2001} & Every hour & $\begin{array}{l}139.09 \mathrm{a} \\
( \pm 10.69)\end{array}$ & $\begin{array}{l}10.42 \mathrm{a} \\
( \pm 2.15)\end{array}$ & $\begin{array}{c}2.87 \mathrm{a} \\
( \pm 0.23)\end{array}$ & $\begin{array}{l}45.60 \mathrm{a} \\
( \pm 4.06)\end{array}$ & $\begin{array}{l}18.89 \mathrm{a} \\
( \pm 2.18)\end{array}$ & $\begin{array}{l}241.20 \mathrm{a} \\
( \pm 17.63)\end{array}$ & $\begin{array}{c}6.80 \mathrm{a} \\
( \pm 2.57)\end{array}$ & $\begin{array}{l}17.56 \mathrm{a} \\
( \pm 2.06)\end{array}$ & $\begin{array}{l}15.88 \mathrm{a} \\
( \pm 2.57)\end{array}$ & $\begin{array}{l}10.14 \mathrm{a} \\
( \pm 1.47)\end{array}$ & $\begin{array}{c}1.89 \mathrm{a} \\
( \pm 0.37)\end{array}$ & $\begin{array}{c}0.49 \mathrm{a} \\
( \pm 0.11)\end{array}$ & $\begin{array}{l}45.96 \mathrm{a} \\
( \pm 3.17)\end{array}$ \\
\hline & Every 3 hours & $\begin{array}{l}151.91 \mathrm{a} \\
( \pm 22.69)\end{array}$ & $\begin{array}{c}7.25 \mathrm{~b} \\
( \pm 3.33)\end{array}$ & $\begin{array}{c}3.05 \mathrm{a} \\
( \pm 0.35)\end{array}$ & $\begin{array}{l}48.55 \mathrm{a} \\
( \pm 7.23)\end{array}$ & $\begin{array}{l}19.79 \mathrm{a} \\
( \pm 4.17)\end{array}$ & $\begin{array}{l}254.93 \mathrm{a} \\
( \pm 34.96)\end{array}$ & $\begin{array}{c}6.77 \mathrm{a} \\
( \pm 2.03)\end{array}$ & $\begin{array}{l}17.47 \mathrm{a} \\
( \pm 2.68)\end{array}$ & $\begin{array}{l}15.22 \mathrm{a} \\
( \pm 1.79)\end{array}$ & $\begin{array}{c}9.97 \mathrm{a} \\
( \pm 1.05)\end{array}$ & $\begin{array}{c}1.79 \mathrm{a} \\
( \pm 0.29)\end{array}$ & $\begin{array}{c}0.80 \mathrm{a} \\
( \pm 0.06)\end{array}$ & $\begin{array}{l}44.94 \mathrm{a} \\
( \pm 5.11)\end{array}$ \\
\hline \multirow[t]{2}{*}{2002} & Every hour & $\begin{array}{l}173.79 \mathrm{a} \\
( \pm 9.25)\end{array}$ & $\begin{array}{c}6.38 \mathrm{a} \\
( \pm 1.57)\end{array}$ & $\begin{array}{c}3.63 \mathrm{a} \\
( \pm 0.25)\end{array}$ & $\begin{array}{l}51.12 \mathrm{a} \\
( \pm 3.53)\end{array}$ & $\begin{array}{l}24.41 \mathrm{a} \\
( \pm 3.06)\end{array}$ & $\begin{array}{l}289.27 \mathrm{a} \\
( \pm 16.23)\end{array}$ & $\begin{array}{c}8.53 \mathrm{a} \\
( \pm 2.07)\end{array}$ & $\begin{array}{l}10.61 \mathrm{a} \\
( \pm 2.12)\end{array}$ & $\begin{array}{c}7.91 \mathrm{a} \\
( \pm 0.78)\end{array}$ & $\begin{array}{c}9.18 \mathrm{a} \\
( \pm 0.74)\end{array}$ & $\begin{array}{c}3.07 \mathrm{a} \\
( \pm 0.89)\end{array}$ & $\begin{array}{c}0.23 \mathrm{a} \\
( \pm 0.17)\end{array}$ & $\begin{array}{l}31.29 \mathrm{a} \\
( \pm 4.08)\end{array}$ \\
\hline & Every 3 hours & $\begin{array}{l}169.05 \mathrm{a} \\
( \pm 21.76)\end{array}$ & $\begin{array}{c}5.67 \mathrm{a} \\
( \pm 1.66)\end{array}$ & $\begin{array}{c}3.56 \mathrm{a} \\
( \pm 0.54)\end{array}$ & $\begin{array}{l}51.29 \mathrm{a} \\
( \pm 5.78)\end{array}$ & $\begin{array}{l}25.33 \mathrm{a} \\
( \pm 4.04)\end{array}$ & $\begin{array}{l}284.51 \mathrm{a} \\
( \pm 36.10)\end{array}$ & $\begin{array}{l}7.42 \text { a x } \\
( \pm 36.10)\end{array}$ & $\begin{array}{c}8.94 \mathrm{a} \\
( \pm 2.12)\end{array}$ & $\begin{array}{c}7.10 \mathrm{~b} \\
( \pm 1.02)\end{array}$ & $\begin{array}{l}8.22 \mathrm{~b} \\
( \pm 0.91)\end{array}$ & $\begin{array}{c}3.03 \mathrm{a} \\
( \pm 0.95)\end{array}$ & $\begin{array}{c}0.22 \mathrm{a} \\
( \pm 0.17)\end{array}$ & $\begin{array}{l}27.82 \mathrm{~b} \\
( \pm 4.75)\end{array}$ \\
\hline
\end{tabular}

${ }^{\mathrm{a}} \mathrm{mg} / \mathrm{L}$ unless otherwise noted; ${ }^{\mathrm{b}} \mathrm{mg}$ corresponding anthocyanin-3-Glc equivalents/L; ${ }^{\mathrm{c}}$ sum of phenolic group content; ${ }^{\mathrm{d}}$ mg malvidin-3-Glc equivalents/L; ${ }^{\mathrm{e}}$ mg rutin equivalents $/ \mathrm{L} ;{ }^{\mathrm{f}}$ different letters within a group in a column denote significant differences $(\mathrm{P}<0.05) ;{ }^{\mathrm{g}}$ standard deviation; Dp $=$ delphinidin; Glc $=$ glucoside; Glc-Ac $=$ acetylglucoside; Glc-Coum = p-coumaroylglucoside; $\mathrm{Pt}=$ petunidin; $\mathrm{Pn}=$ peonidin; $\mathrm{Mv}=$ malvidin; $\mathrm{Q}=\mathrm{quercetin} ;$ rham = rhamnoside . 
TABLE 5

Phenolic acid, flavan-3-ol, non-coloured polymer and total monomer contents ${ }^{\mathrm{a}}$ of the 2001 and 2002 Pinotage wines produced according to different juice/skin mixing protocols and mixing frequencies.

\begin{tabular}{|c|c|c|c|c|c|c|c|c|c|c|c|}
\hline \multirow{2}{*}{ Year } & \multirow{2}{*}{$\begin{array}{l}\text { Treatment/ } \\
\text { Frequency }\end{array}$} & \multicolumn{6}{|c|}{ Phenolic acids } & \multicolumn{3}{|c|}{ Flavan-3-ols } & \multirow{2}{*}{$\begin{array}{c}\text { Total } \\
\text { monomers }\end{array}$} \\
\hline & & $\begin{array}{l}\text { Gallic } \\
\text { acid }\end{array}$ & $\begin{array}{l}\text { Caftaric } \\
\text { acid }\end{array}$ & $\begin{array}{c}\text { Caffeic } \\
\text { acid }\end{array}$ & $\begin{array}{l}\text { Coutaric } \\
\text { acid }^{b}\end{array}$ & $\begin{array}{c}p \text {-Coumaric } \\
\text { acid }\end{array}$ & Total $^{\mathrm{c}}$ & $\begin{array}{c}(+)- \\
\text { Catechin }\end{array}$ & $\begin{array}{c}\text { Procyanidin } \\
\text { B1 }\end{array}$ & $\begin{array}{l}\text { Non-coloured } \\
\text { polymers }^{\mathrm{d}}\end{array}$ & \\
\hline \multirow[t]{3}{*}{2001} & Punching-down & $\begin{array}{l}13.99 \mathrm{a}^{\mathrm{f}} \\
( \pm 0.57)^{\mathrm{g}}\end{array}$ & $\begin{array}{l}196.87 \mathrm{a} \\
( \pm 22.27)\end{array}$ & $\begin{array}{c}1.24 \mathrm{a} \\
( \pm 0.10)\end{array}$ & $\begin{array}{l}22.45 \mathrm{a} \\
( \pm 2.63)\end{array}$ & $\begin{array}{c}2.27 \mathrm{a} \\
( \pm 0.58)\end{array}$ & $\begin{array}{l}236.81 \mathrm{a} \\
( \pm 25.03)\end{array}$ & $\begin{array}{l}10.49 a \\
( \pm 0.44)\end{array}$ & $\begin{array}{l}17.13 \mathrm{a} \\
( \pm 0.94)\end{array}$ & $\begin{array}{l}175.18 \mathrm{a} \\
( \pm 20.75)\end{array}$ & $\begin{array}{l}572.95 \mathrm{a} \\
( \pm 40.30)\end{array}$ \\
\hline & Pumping-over & $\begin{array}{l}13.27 \mathrm{a} \\
( \pm 1.23)\end{array}$ & $\begin{array}{l}161.14 \mathrm{~b} \\
( \pm 26.26)\end{array}$ & $\begin{array}{c}1.31 \mathrm{a} \\
( \pm 0.12)\end{array}$ & $\begin{array}{l}19.47 \mathrm{~b} \\
( \pm 3.09)\end{array}$ & $\begin{array}{c}1.70 \mathrm{a} \\
( \pm 0.58)\end{array}$ & $\begin{array}{l}196.89 \mathrm{~b} \\
( \pm 30.53)\end{array}$ & $\begin{array}{l}10.48 \mathrm{a} \\
( \pm 0.55)\end{array}$ & $\begin{array}{l}18.24 \mathrm{a} \\
( \pm 1.04)\end{array}$ & $\begin{array}{l}179.92 \mathrm{a} \\
( \pm 46.14)\end{array}$ & $\begin{array}{l}519.14 b \\
( \pm 20.13)\end{array}$ \\
\hline & Rotor & $\begin{array}{l}13.10 \mathrm{a} \\
( \pm 1.31)\end{array}$ & $\begin{array}{l}172.23 \mathrm{~b} \\
( \pm 14.51)\end{array}$ & $\begin{array}{c}1.21 \mathrm{a} \\
( \pm 0.16)\end{array}$ & $\begin{array}{l}20.48 \mathrm{ab} \\
( \pm 2.06)\end{array}$ & $\begin{array}{c}2.08 \mathrm{a} \\
( \pm 0.44)\end{array}$ & $\begin{array}{l}209.09 \mathrm{~b} \\
( \pm 15.59)\end{array}$ & $\begin{array}{c}9.89 \mathrm{~b} \\
( \pm 0.47)\end{array}$ & $\begin{array}{l}16.42 \mathrm{a} \\
( \pm 1.92)\end{array}$ & $\begin{array}{l}167.80 \mathrm{a} \\
( \pm 11.21)\end{array}$ & $\begin{array}{l}513.91 \mathrm{~b} \\
( \pm 28.94)\end{array}$ \\
\hline \multirow[t]{3}{*}{2002} & Punching-down & $\begin{array}{l}13.35 \mathrm{a} \\
( \pm 1.82)\end{array}$ & $\begin{array}{l}176.62 \mathrm{c} \\
( \pm 18.25)\end{array}$ & $\begin{array}{c}1.94 \mathrm{a} \\
( \pm 1.12)\end{array}$ & $\begin{array}{l}17.48 \mathrm{c} \\
( \pm 1.08)\end{array}$ & $\begin{array}{c}1.69 \mathrm{~b} \\
( \pm 0.21)\end{array}$ & $\begin{array}{l}211.10 \mathrm{c} \\
( \pm 17.17)\end{array}$ & $\begin{array}{c}9.90 \mathrm{~b} \\
( \pm 0.49)\end{array}$ & $\begin{array}{l}17.33 \mathrm{a} \\
( \pm 1.14)\end{array}$ & $\begin{array}{r}195.86 \mathrm{a} \\
( \pm 25.09)\end{array}$ & $\begin{array}{l}568.77 \mathrm{~b} \\
( \pm 20.08)\end{array}$ \\
\hline & Pumping-over & $\begin{array}{l}11.76 \mathrm{~b} \\
( \pm 0.82)\end{array}$ & $\begin{array}{l}209.51 \mathrm{~b} \\
( \pm 23.39)\end{array}$ & $\begin{array}{c}1.05 \mathrm{~b} \\
( \pm 0.17)\end{array}$ & $\begin{array}{l}20.20 \mathrm{~b} \\
( \pm 2.21)\end{array}$ & $\begin{array}{c}2.15 \mathrm{a} \\
( \pm 0.43)\end{array}$ & $\begin{array}{l}244.66 \mathrm{~b} \\
( \pm 26.22)\end{array}$ & $\begin{array}{c}9.67 \mathrm{~b} \\
( \pm 0.51)\end{array}$ & $\begin{array}{l}17.05 \mathrm{a} \\
( \pm 1.68)\end{array}$ & $\begin{array}{l}151.61 \mathrm{~b} \\
( \pm 17.36)\end{array}$ & $\begin{array}{l}566.11 \mathrm{~b} \\
( \pm 26.37)\end{array}$ \\
\hline & Rotor & $\begin{array}{l}13.77 \mathrm{a} \\
( \pm 0.89)\end{array}$ & $\begin{array}{l}235.90 \mathrm{a} \\
( \pm 12.26)\end{array}$ & $\begin{array}{c}1.07 \mathrm{~b} \\
( \pm 0.14)\end{array}$ & $\begin{array}{l}22.96 \mathrm{a} \\
( \pm 0.86)\end{array}$ & $\begin{array}{c}2.29 \mathrm{a} \\
( \pm 0.38)\end{array}$ & $\begin{array}{l}275.99 \mathrm{a} \\
( \pm 12.76)\end{array}$ & $\begin{array}{l}10.63 \mathrm{a} \\
( \pm 0.77)\end{array}$ & $\begin{array}{l}16.05 \mathrm{a} \\
( \pm 0.94)\end{array}$ & $\begin{array}{l}189.22 \mathrm{a} \\
( \pm 21.92)\end{array}$ & $\begin{array}{l}626.83 \mathrm{a} \\
( \pm 17.35)\end{array}$ \\
\hline \multirow[t]{2}{*}{2001} & Every hour & $\begin{array}{r}12.98 \mathrm{a} \\
( \pm 0.90)\end{array}$ & $\begin{array}{c}190.95 \mathrm{a} \\
( \pm 22.63)\end{array}$ & $\begin{array}{c}1.26 \mathrm{a} \\
( \pm 0.14)\end{array}$ & $\begin{array}{l}22.46 \mathrm{a} \\
( \pm 2.35)\end{array}$ & $\begin{array}{c}2.24 \mathrm{a} \\
( \pm 0.49)\end{array}$ & $\begin{array}{l}229.89 \mathrm{a} \\
( \pm 25.58)\end{array}$ & $\begin{array}{l}10.56 \mathrm{a} \\
( \pm 0.36)\end{array}$ & $\begin{array}{l}17.15 \mathrm{a} \\
( \pm 1.33)\end{array}$ & $\begin{array}{c}178.45 a \\
( \pm 34.68)\end{array}$ & $\begin{array}{l}544.76 \mathrm{a} \\
( \pm 43.34)\end{array}$ \\
\hline & Every 3 hours & $\begin{array}{l}13.92 \mathrm{a} \\
( \pm 1.11)\end{array}$ & $\begin{array}{l}162.54 \mathrm{~b} \\
( \pm 20.19)\end{array}$ & $\begin{array}{c}1.25 \mathrm{a} \\
( \pm 0.12)\end{array}$ & $\begin{array}{l}19.14 b \\
( \pm 2.17)\end{array}$ & $\begin{array}{c}1.79 \mathrm{a} \\
( \pm 0.56)\end{array}$ & $\begin{array}{l}198.64 b \\
( \pm 23.45)\end{array}$ & $\begin{array}{l}10.01 \mathrm{~b} \\
( \pm 0.57)\end{array}$ & $\begin{array}{l}17.38 \mathrm{a} \\
( \pm 1.74)\end{array}$ & $\begin{array}{l}170.15 \mathrm{a} \\
( \pm 22.20)\end{array}$ & $\begin{array}{l}525.90 \mathrm{a} \\
( \pm 36.26)\end{array}$ \\
\hline \multirow[t]{2}{*}{2002} & Every hour & $\begin{array}{l}13.70 \mathrm{a} \\
( \pm 1.71)\end{array}$ & $\begin{array}{l}195.34 \mathrm{~b} \\
( \pm 32.59)\end{array}$ & $\begin{array}{c}1.69 \mathrm{a} \\
( \pm 0.97)\end{array}$ & $\begin{array}{l}19.26 \mathrm{~b} \\
( \pm 2.83)\end{array}$ & $\begin{array}{c}1.82 \mathrm{~b} \\
( \pm 0.31)\end{array}$ & $\begin{array}{l}231.82 \mathrm{~b} \\
( \pm 35.10)\end{array}$ & $\begin{array}{l}10.27 \mathrm{a} \\
( \pm 0.84)\end{array}$ & $\begin{array}{c}17.27 \mathrm{a} \\
( \pm 1.11)\end{array}$ & $\begin{array}{l}191.14 \mathrm{a} \\
( \pm 28.12)\end{array}$ & $\begin{array}{l}579.92 \mathrm{a} \\
( \pm 45.06)\end{array}$ \\
\hline & Every 3 hours & $\begin{array}{l}12.23 \mathrm{~b} \\
( \pm 0.73)\end{array}$ & $\begin{array}{l}219.34 \mathrm{a} \\
( \pm 24.11)\end{array}$ & $\begin{array}{c}1.02 \mathrm{~b} \\
( \pm 0.14)\end{array}$ & $\begin{array}{l}21.16 \mathrm{a} \\
( \pm 2.33)\end{array}$ & $\begin{array}{c}2.26 \mathrm{a} \\
( \pm 0.42)\end{array}$ & $\begin{array}{l}256.01 \mathrm{a} \\
( \pm 27.10)\end{array}$ & $\begin{array}{c}9.87 \mathrm{a} \\
( \pm 0.51)\end{array}$ & $\begin{array}{l}16.34 \mathrm{a} \\
( \pm 1.44)\end{array}$ & $\begin{array}{l}166.65 \mathrm{~b} \\
( \pm 24.67)\end{array}$ & $\begin{array}{l}594.55 \mathrm{a} \\
( \pm 42.49)\end{array}$ \\
\hline
\end{tabular}

${ }^{\mathrm{a}} \mathrm{mg} / \mathrm{L}$ unless otherwise noted; ${ }^{\mathrm{b}} \mathrm{mg}$ p-coumaric acid equivalents/L; ${ }^{\mathrm{c}}$ sum of quantified compounds in group; ${ }^{\mathrm{d}}$ mg $(+)$-catechin equivalents/L; ${ }^{\mathrm{e}}$ sum of all quantified monomeric phenolic compounds; ${ }^{\mathrm{f}}$ different letters in a column within a group indicate significant differences $(\mathrm{P}<0.05)$; ${ }^{\mathrm{g}}$ standard deviation.

Similarly to the individual anthocyanins, the mixing technique did not affect the total or individual flavonol contents of the 2001 wines, except for a $17 \%$ lower kaempferol content as a result of the rotor action compared to the punching-down action (see Table 4). Pumping-over gave wines with lower quercetin-3-Glc (15\%), quercetin-3-Rham (22\%) and the unknown flavonol (19\%) contents in 2002 than those obtained with the punchingdown treatment. It also gave wines with a lower content of the two aglycons, quercetin (34\%) and kaempferol (68\%), than the rotor treatment.

The total phenolic acid content of the 2001 and 2002 wines was affected by the mixing technique, but whereas punching-down gave the highest total phenolic acid content in 2001, the lowest content was obtained in 2002 with the same technique (Table 5). Only the caftaric and coutaric acid contents of the 2001 wines were affected by the mixing technique, with punching-down giving 22 and $14 \%$ better extraction of caftaric acid than both the pumping-over and rotor treatments, respectively, and its extraction of coutaric acid was $16 \%$ better than with the pumping-over treatment. All the respective phenolic acids' contents of the 2002 wines were affected by mixing technique, although not in the same manner. Punching-down gave wines with more than $80 \%$ higher caffeic acid content in 2002 than the other juice/skin mixing treatments, but between 13 and $25 \%$ lower caftaric and coutaric acid contents. The pumping-over and rotor treatments gave wines with a 21 and $26 \%$ higher $p$-coumaric acid content, respectively, than the punching-down treatment. For extraction of gallic acid, pumping-over was $12 \%$ less effective than punching-down.

Considering individual flavan-3-ols, extraction of the dimer, procyanidin B1, was not affected by the mixing technique (Table 5). However, the (+)-catechin content was affected, with the rotor treatment resulting in wines with $6 \%$ lower content in 2001 than the punching-down treatment, and $7 \%$ higher content in 2002. The non-coloured polymer content was also affected by the mixing technique in 2002, with the pumping-over treatment giving wines with $23 \%$ lower content than the punching-down treatment.

Adding up all the individual monomeric phenolic compounds, quantified using HPLC, the punching-down treatment in 2001 and rotor treatment in 2002 resulted in wines with about $10 \%$ higher total monomer content (HPLC) than the pumping-over treatment (Table 5).

Mixing frequency had a limited effect on the phenolic composition of the 2001 wines. Their vitisin A (44\%), caftaric acid $(17 \%)$, coutaric acid $(15 \%)$, total phenolic acid (14\%) and (+)catechin $(5 \%)$ contents were increased by the higher mixing frequency (Tables 4,5$)$. On the other hand, the caftaric $(11 \%)$, 
coutaric (9\%), p-coumaric (19\%) and total phenolic acid (9\%) contents of the 2002 wines decreased with the higher mixing frequency. The polymeric anthocyanin ( $\mathrm{pH}$ shift) (19\%), total flavan-3-ol (DAC) (8\%), non-coloured polymer (15\%), quercetin-3Glc $(11 \%)$, quercetin-3-Rham (12\%) and total flavonol (12\%) contents, as well as gallic (12\%) and caffeic (92\%) acid contents, of the wines were increased when hourly mixing was used during maceration (Tables 3-5).

\section{Juice/Skin mixing during maceration: effect on antioxidant capacity}

The effect of the different juice/skin mixing techniques during maceration on the antioxidant capacity of Pinotage wines is summarised in Table 6 . The pumping-over and rotor treatments yielded wines in 2000 with $11 \%$ lower and $12 \%$ higher $\mathrm{TAC}_{\mathrm{M}}$ values, respectively, than the punching-down treatment.

The $\mathrm{TAC}_{\mathrm{CAL}}$ (Table 6) of the 2001 wines, as well as the contribution of phenolic acids to the $\mathrm{TAC}_{\mathrm{CAL}}$ (Fig. 6), was higher when the punching-down treatment rather than the other mixing techniques was used. The $\mathrm{TAC}_{\mathrm{M}}$ and $\mathrm{TAC}_{\mathrm{R}}$ of the 2001 wines were, however, not affected. Also for this vintage, the pumping-over treatment resulted in wines with a higher flavan-3-ol contribution to the $\mathrm{TAC}_{\mathrm{CAL}}$ than the rotor treatment. The contributions by flavonols and anthocyanins to the $\mathrm{TAC}_{\mathrm{CAL}}$ were not affected by the mixing technique.

In 2002 , the $\mathrm{TAC}_{\mathrm{M}}(12 \%)$ and $\mathrm{TAC}_{\mathrm{R}}(13 \%)$ of the wines were lower when the pumping-over treatment instead of the punchingdown treatment was used (Table 6). The $\mathrm{TAC}_{\mathrm{CAL}}$ and the contributions of phenolic acids and flavonols to the $\mathrm{TAC}_{\mathrm{CAL}}$ (Fig. 6) were higher when the rotor treatment, instead of the pumping- over treatment was used. The contribution of phenolic acids to the TAC $_{\mathrm{CAL}}$ was also higher than that obtained with the punchingdown treatment. The punching-down and rotor treatments, however, resulted in wines with higher flavonol contributions than the pumping-over treatment. No significant differences were observed between the mixing techniques in terms of flavan-3-ol and anthocyanin contributions. In all cases the contribution of flavan-3-ols and flavonols to the $\mathrm{TAC}_{\mathrm{CAL}}$ was small.

The mixing frequency had no effect on the antioxidant capacity of the 2000 and 2001 wines (Table 6). The higher mixing frequency increased the $\mathrm{TAC}_{\mathrm{M}}(7 \%)$ and $\mathrm{TAC}_{\mathrm{R}}(8 \%)$ of the 2002 wines. Only the contribution of phenolic acids to the TAC $\mathrm{CAL}_{\mathrm{C}}$ was affected by mixing frequency. However, opposite effects for the 2001 and 2002 wines were obtained (Fig. 7).

\section{Juice/Skin mixing during maceration: objective colour para- meters}

Similar to the phenolic composition and antioxidant capacity, mixing techniques did not significantly affect the objective colour parameters of the 2001 wines (Table 6). The pumping-over treatment resulted in wines having between 4 and 19\% lower $C^{*}, a^{*}$ and $b^{*}$ values and between 14 and $27 \%$ higher $L^{*}$ values in 2000 and 2002 than the punching-down treatment. Considering the 2002 wines, $h^{*}$ was $15 \%$ lower when the pumping-over treatment was used compared to the punching-down treatment. The rotor treatment gave wines with the highest $C^{*}$ and $a^{*}$ values. Mixing frequencies did not significantly affect the objective colour parameters of the 2000 and 2001 wines. Hourly mixing gave wines with $17 \%$ higher $h^{*}$ and $21 \%$ higher $b^{*}$ values in 2001 than $3-$ hourly mixing.

\section{TABLE 6}

Antioxidant capacity and objective colour parameters of the 2000, 2001 and 2002 Pinotage wines produced according to different juice/skin mixing protocols and mixing frequencies.

\begin{tabular}{|c|c|c|c|c|c|c|c|c|c|}
\hline \multirow{2}{*}{ Year } & \multirow{2}{*}{$\begin{array}{l}\text { Treatment/ } \\
\text { Frequency }\end{array}$} & \multicolumn{3}{|c|}{ Antioxidant capacity } & \multicolumn{5}{|c|}{ Objective colour parameters } \\
\hline & & $\mathrm{TAC}_{\mathbf{M}^{\mathrm{a}}}$ & TAC $_{\text {CAL }}{ }^{b}$ & $\operatorname{TAC}_{R}{ }^{c}$ & $\mathrm{C}^{* d}$ & $\mathbf{h}^{* e}$ & $\mathrm{~L}^{* f}$ & $\mathrm{a}^{* g}$ & $\mathrm{~b}^{* h}$ \\
\hline \multirow[t]{3}{*}{2000} & Punching-down & $11.83 b^{\mathrm{i}}( \pm 0.93)^{\mathrm{j}}$ & na & na & $60.29 \mathrm{a}( \pm 1.28)$ & 18.04 a $( \pm 0.69)$ & $36.39 \mathrm{~b}( \pm 2.64)$ & $57.32 \mathrm{a}( \pm 1.15)$ & $18.67 \mathrm{a}( \pm 0.93)$ \\
\hline & Pumping-over & $10.58 \mathrm{c}( \pm 0.54)$ & na & na & $53.72 \mathrm{~b}( \pm 3.25)$ & $16.68 \mathrm{a}( \pm 1.56)$ & $46.19 \mathrm{a}( \pm 4.20)$ & $51.44 \mathrm{~b}( \pm 2.99)$ & $15.44 \mathrm{~b}( \pm 1.94)$ \\
\hline & Rotor & $13.22 \mathrm{a}( \pm 1.34)$ & na & na & $59.30 \mathrm{a}( \pm 1.06)$ & $16.76 \mathrm{a}( \pm 1.71)$ & $40.41 \mathrm{~b}( \pm 3.50)$ & $56.76 \mathrm{a}( \pm 0.85)$ & $17.10 \mathrm{ab}( \pm 1.88)$ \\
\hline \multirow[t]{3}{*}{2001} & Punching-down & $16.00 \mathrm{a}( \pm 1.04)$ & 1.73 a $( \pm 0.11)$ & $14.28 \mathrm{a}( \pm 0.99)$ & $62.15 \mathrm{a}( \pm 0.58)$ & $14.31 \mathrm{a}( \pm 1.35)$ & $33.70 \mathrm{a}( \pm 4.01)$ & $60.21 \mathrm{a}( \pm 0.39)$ & $15.37 \mathrm{a}( \pm 1.52)$ \\
\hline & Pumping-over & 15.51 a $( \pm 0.59)$ & $1.58 \mathrm{~b}( \pm 0.05)$ & $13.93 \mathrm{a}( \pm 0.55)$ & $62.28 \mathrm{a}( \pm 1.88)$ & $14.12 \mathrm{a}( \pm 2.19)$ & $36.85 \mathrm{a}( \pm 5.30)$ & $60.35 \mathrm{a}( \pm 1.39)$ & $15.23 \mathrm{a}( \pm 2.68)$ \\
\hline & Rotor & 15.55 a $( \pm 0.56)$ & $1.56 \mathrm{~b}( \pm 0.09)$ & $14.00 \mathrm{a}( \pm 0.52)$ & $63.03 \mathrm{a}( \pm 1.28)$ & $15.00 \mathrm{a}( \pm 1.70)$ & $34.82 \mathrm{a}( \pm 3.50)$ & $60.85 \mathrm{a}( \pm 0.80)$ & $16.33 \mathrm{a}( \pm 2.11)$ \\
\hline \multirow[t]{3}{*}{2002} & Punching-down & $17.20 \mathrm{a}( \pm 1.22)$ & $1.76 \mathrm{~b}( \pm 0.13)$ & $15.44 \mathrm{a}( \pm 1.21)$ & $60.19 \mathrm{ab}( \pm 2.13)$ & 12.69 a $( \pm 2.27)$ & $40.48 \mathrm{~b}( \pm 4.08)$ & $58.67 \mathrm{ab}( \pm 1.66)$ & $13.27 \mathrm{a}( \pm 2.73)$ \\
\hline & Pumping-over & $15.37 \mathrm{~b}( \pm 1.06)$ & $1.73 b( \pm 0.08)$ & $13.65 \mathrm{~b}( \pm 1.01)$ & $57.11 \mathrm{~b}( \pm 4.64)$ & $10.77 \mathrm{~b}( \pm 1.21)$ & $46.05 \mathrm{a}( \pm 5.70)$ & $56.08 \mathrm{~b}( \pm 4.36)$ & $10.74 \mathrm{~b}( \pm 2.00)$ \\
\hline & Rotor & 17.99 a $( \pm 0.60)$ & $1.91 \mathrm{a}( \pm 0.05)$ & $16.07 \mathrm{a}( \pm 0.56)$ & $62.09 \mathrm{a}( \pm 1.19)$ & $12.63 \mathrm{a}( \pm 0.96)$ & $39.03 \mathrm{~b}( \pm 1.68)$ & $60.58 \mathrm{a}( \pm 1.04)$ & $13.59 \mathrm{a}( \pm 1.18)$ \\
\hline \multirow[t]{2}{*}{2000} & Every hour & $11.66 \mathrm{a}( \pm 1.82)$ & na & na & $57.84 \mathrm{a}( \pm 2.99)$ & $17.40 \mathrm{a}( \pm 1.35)$ & $40.05 \mathrm{a}( \pm 4.70)$ & $55.18 \mathrm{a}( \pm 2.86)$ & $17.29 \mathrm{a}( \pm 1.62)$ \\
\hline & Every 3 hours & $12.09 \mathrm{a}( \pm 1.04)$ & na & na & $57.70 \mathrm{a}( \pm 4.27)$ & $16.91 \mathrm{a}( \pm 1.61)$ & $41.95 \mathrm{a}( \pm 5.95)$ & $55.17 \mathrm{a}( \pm 3.81)$ & $16.85 \mathrm{a}( \pm 2.51)$ \\
\hline \multirow[t]{2}{*}{2001} & Every hour & 15.80 a $( \pm 0.87)$ & $1.64 \mathrm{a} \quad( \pm 0.12)$ & $14.17 \mathrm{a}( \pm 0.81)$ & $62.85 \mathrm{a}( \pm 1.23)$ & $14.23 \mathrm{a}( \pm 2.02)$ & $35.00 \mathrm{a}( \pm 2.91)$ & $60.77 \mathrm{a}( \pm 0.89)$ & 15.99 a $( \pm 1.77)$ \\
\hline & Every 3 hours & 15.57 a $( \pm 0.64)$ & $1.60 \mathrm{a} \quad( \pm 0.11)$ & $13.97 \mathrm{a}( \pm 0.58)$ & $62.12 \mathrm{a}( \pm 1.40)$ & $14.72 \mathrm{a}( \pm 1.42)$ & $35.25 \mathrm{a}( \pm 5.53)$ & $60.17 \mathrm{a}( \pm 0.94)$ & $15.29 \mathrm{a}( \pm 2.42)$ \\
\hline \multirow[t]{2}{*}{2002} & Every hour & $17.42 \mathrm{a}( \pm 1.32)$ & $1.79 \mathrm{a} \quad( \pm 0.12)$ & $15.64 \mathrm{a}( \pm 1.26)$ & $60.95 \mathrm{a}( \pm 2.54)$ & $12.98 \mathrm{a}( \pm 1.81)$ & $40.05 \mathrm{a}( \pm 4.32)$ & $59.36 \mathrm{a}( \pm 2.20)$ & $13.73 \mathrm{a}( \pm 2.29)$ \\
\hline & Every 3 hours & $16.28 \mathrm{~b}( \pm 1.43)$ & $1.81 \mathrm{a} \quad( \pm 0.13)$ & $14.47 \mathrm{~b}( \pm 1.33)$ & $58.64 \mathrm{a}( \pm 4.15)$ & $11.08 \mathrm{~b}( \pm 1.09)$ & $43.66 \mathrm{a}( \pm 5.20)$ & $57.53 \mathrm{a}( \pm 3.90)$ & $11.33 \mathrm{~b}( \pm 1.78)$ \\
\hline
\end{tabular}

${ }^{\mathrm{a}}$ total antioxidant capacity in $\mathrm{mM}$ Trolox equivalents; ${ }^{\mathrm{b}}$ total antioxidant capacity in $\mathrm{mM}$ Trolox equivalents as calculated from the content of monomeric phenolic compounds and their Trolox equivalent antioxidant capacity; ${ }^{\mathrm{c}} \mathrm{TAC}_{\mathrm{R}}=\mathrm{TAC}_{\mathrm{M}}-\mathrm{TAC}_{\mathrm{CAL}} ;{ }^{\mathrm{d}}$ chroma; ${ }^{\mathrm{e}}$ hue angle $\left({ }^{\circ}\right) ;{ }^{\mathrm{f}}$ lightness; ${ }^{\mathrm{g}}$ red/green chromaticity; ${ }^{\mathrm{h}}$ yellow/blue chromaticity; ${ }^{\mathrm{i}}$ different letters within a group in a column denote significant differences $(\mathrm{P}<0.05) ;{ }^{\mathrm{j}}$ standard deviation; na $=$ not available. 


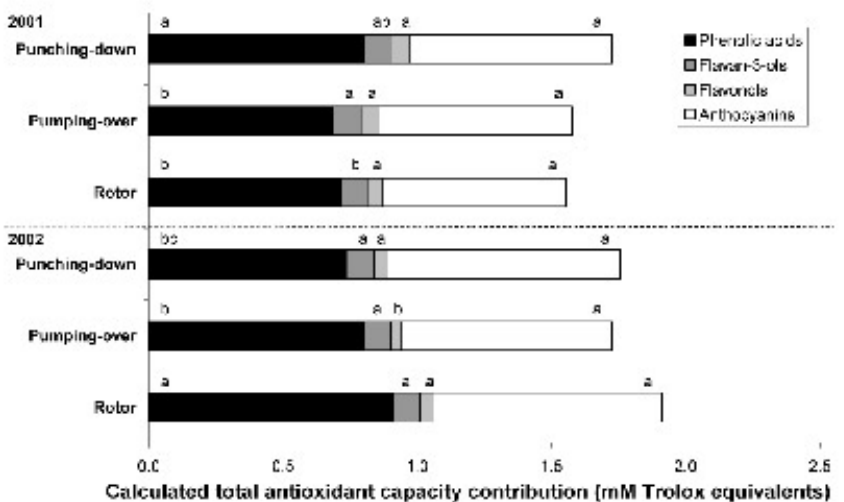

FIGURE 6

Calculated total antioxidant capacity contributions of phenolic groups for the 2001 and 2002 Pinotage wines produced according to different juice/skin mixing protocols [different letters for the contribution of a specific phenolic group in the same year denote significant differences $(\mathrm{P}<0.05)]$.

\section{DISCUSSION}

\section{Vintage-related variation}

Vintage-related variation, in terms of phenolic composition, total antioxidant capacity and colour, as were also observed in De Beer et al. (2006b), is presumably due to variation in weather patterns during the respective vintages. Important factors include average minimum and maximum temperatures, rainfall and sunlight radiation. Timing of specific weather events (rainfall, heavy winds and temperature extremes), especially during the ripening season, will also have an effect on grape composition. Furthermore, the trends between the vintages were not consistent for the two trials, indicating that other factors also contributed to the vintage-related variation. The grapes for both trials were harvested on the same day from the same vineyard block and winemaking commenced simultaneously. Due to this, the effect of vintage will be discussed separately for the pre-fermentation maceration and juice/skin mixing trials.

In terms of antioxidant capacity, the difference in phenolic composition between the 2001 and 2002 wines of the pre-fermentation maceration trial did not manifest in significant differences in $\mathrm{TAC}_{\mathrm{M}}$. However, the increased $\mathrm{TAC}_{\mathrm{CAL}}$, which is due to increased monomeric anthocyanin content, and increased $T_{A} C_{R}$ explained the higher $\mathrm{TAC}_{\mathrm{M}}$ for the 2002 wines, compared to the 2001 wines of the juice/skin mixing trial. The low $\mathrm{TAC}_{\mathrm{M}}$ of the 2000 wines is presumably due to weather conditions influencing the grape composition of this vintage.

The wines from the 2002 vintage for the pre-fermentation maceration trial had substantially higher chromaticity values than wines of the other vintages. The higher $a^{*}$ and $b^{*}$ values were not supported by compositional data, since the individual monomeric anthocyanin (mainly red pigments) and flavonol (mainly yellow pigments) contents of the 2002 wines were either not significantly different from or substantially lower than that of the 2001 wines. Not only is pigment concentration important, but other factors such as $\mathrm{pH}$, sulphur dioxide content and co-pigmentation effects can also influence chromaticity (Gonnet, 1999). Sulphur dioxide is, however, not expected to play an important role in anthocyanin bleaching, in this case, as all juice/skin mixing trial

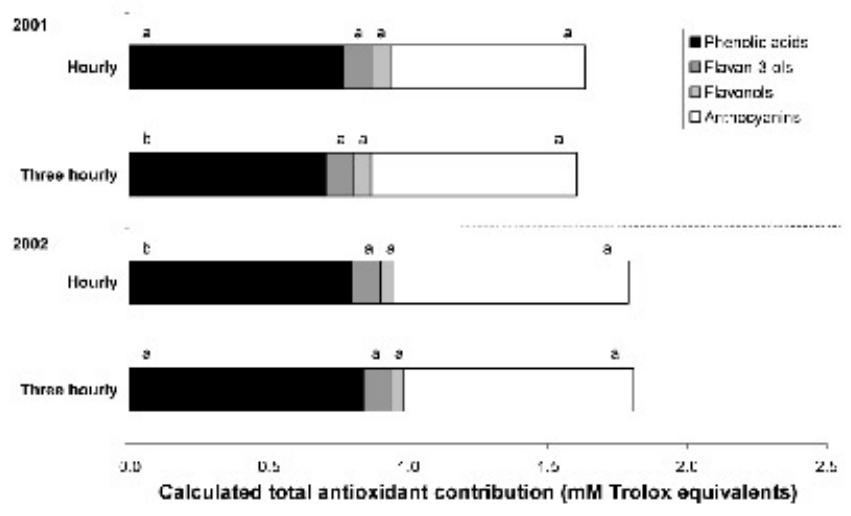

FIGURE 7

Calculated total antioxidant capacity contributions of phenolic groups for the 2001 and 2002 Pinotage wines produced with different juice/skin mixing frequencies [different letters for the contribution of a specific phenolic group in the same year denote significant differences $(\mathrm{P}<0.05)]$.

wines were prepared using the same sulphur dioxide content and stored under the same conditions. As the average $\mathrm{pH}$ of the berries also did not differ between vintages (data not shown), pigment content and co-pigmentation effects are considered to be of importance in this case.

Flavonol glycosides are among the most efficient co-pigments (Asen et al., 1972; Chen \& Hrazdina, 1981). Co-pigmentation has a prominent effect on colour at pH 3.5 (Gonnet, 1999), and would therefore play a large role in wine colour. Generally, lower $L^{*}$ and higher $C^{*}$ values accompanied by bathochromic shifts (blueing) occur with increasing co-pigment concentration (Gonnet, 1999). However, the $C^{*}$ values did not follow the expected pattern, even when taking other less efficient co-pigments, such as flavan-3-ols and phenolic acids, into account. Inversion (Eagerman et al., 1973) as a function of apparatus and measuring conditions, as discussed in De Beer et al. (2006b), could also help explain this atypical behaviour. Inversion occurs especially in dark coloured beverages (Eagerman et al., 1973), which is the case for young red wines such as the ones investigated in the present study. Based on hue angle values, the 2000 and 2001 wines had magenta-red hues, while the major shift in hue of the 2002 wines indicated yellowing towards an orange-red hue.

Concerning wines from the juice/skin mixing trial, the 2001 wines displayed the darkest (lower $L^{*}$ ), most saturated (higher $\left.C^{*}\right)$ colour with higher $a^{*}$ values, attributed to their high polymeric (pH shift) and flavonol (co-pigment) contents. The 2001 wines therefore had the best colour as high values for colour saturation are associated with high red wine quality. The 2000 wines, on the other hand, had the least saturated (lower $C^{*}$ ) colour due to substantially lower $a^{*}$ values and moderately higher $b^{*}$ values. The low monomeric ( $\mathrm{pH}$ shift) and total flavan-3-ol (DAC) (co-pigments) contents of the 2000 wines contributed to their low $C^{*}$ and $a^{*}$ values. The hues of the 2000, 2001 and 2002 wines were all in the magenta-red range, but changed progressively from closer to pure red towards closer to red-magenta hues. These differences in hue are difficult to explain as the 2000 and 2002 wines both had lower total flavan-3-ol contents (co-pigments) than the 2001 wines, while the 2002 wines had lower flavonol contents (co-pigments) than the 2001 wines with no data 
available on the individual phenolic content of the 2000 wines. Inversion is most probably a confounding factor in this case as indicated earlier.

\section{Pre-fermentation maceration}

The results showed that pre-fermentation maceration affected the phenolic composition of the wine, showing significantly varying trends from vintage to vintage due to differences in initial grape composition, especially with regard to phenolic acid content. Prefermentation maceration was expected to increase the anthocyanin content (Heatherbell et al., 1997; Watson et al., 1997; Reynolds et al., 2001; Gómez-Míguez et al., 2006), without affecting the flavan-3-ol content due to the absence of ethanol at this stage (González-Manzano et al., 2004), in contrast to results given by Salinas et al. (2005). In the present study, however, only in some cases, pre-fermentation maceration resulted in higher delphinidin-3-Glc and vitisin A contents with most wines having a similar anthocyanin content to that of the control wine. Only one treatment in 2000, and another in 2001, caused an increase in the total flavan-3-ol content (DAC) of the wine, while two treatments caused decreased concentrations in the 2002 wines. Similar trends were observed for (+)-catechin and procyanidin B1 content in the 2001 and 2002 wines. The decreased total flavan3-ol content did not lead to increased non-coloured or coloured polymer content.

No trends were observed for increased pre-fermentation duration at the same temperature, indicating the complexity of factors influencing the final phenolic content of the wines. Increased duration of pre-fermentation maceration may increase the concentrations of some compounds, but complex reactions between phenolic compounds taking place during, as well as after fermentation, also affect the phenolic composition as measured in the final wine ( 8 months after fermentation), contributing to conflicting results obtained in some cases. For this reason, this discussion will concentrate on individual treatments, explaining their effects on the antioxidant capacity and colour in terms of phenolic composition.

In spite of differences in phenolic composition, the overall effect on $\mathrm{TAC}_{\mathrm{M}}$ was minor. The higher $\mathrm{TAC}_{\mathrm{M}}$ of the wine produced according to the $10^{\circ} \mathrm{C} / 2$ days protocol in 2000 compared to the control wine, is attributed to its higher total phenol and total flavan-3-ol (DAC) contents. The lower $\mathrm{TAC}_{\mathrm{M}}$ of the wine produced according to the $10^{\circ} \mathrm{C} / 4$ days protocol in 2001 , compared to the control wine, is mostly due to lower contributions of unknown flavan-3-ols, as indicated by a lower total flavan-3-ol content (DAC). This is despite no differences in (+)-catechin and procyanidin $\mathrm{B} 1$ contents, and other unknown compounds, indicated by the $\mathrm{TAC}_{\mathrm{R}}$. The phenolic acids and anthocyanins contributed most to the TAC $\mathrm{CAL}_{\mathrm{L}}$ in both the 2001 and 2002 vintages. Higher contributions of total phenolic acids and the high antioxidant potency compounds, (+)-catechin and procyanidin B1 (De Beer et al., 2006a), mostly explain the higher $\mathrm{TAC}_{\mathrm{CAL}}$ of the 2001 wines produced according to the $15^{\circ} \mathrm{C} / 2$ days and $15^{\circ} \mathrm{C} / 4$ days protocols. The $15^{\circ} \mathrm{C} / 4$ days treatment resulted in wines with substantially decreased caftaric acid content and a lower content of most individual anthocyanins in 2002, except peonidin-3-Glc, vitisin $\mathrm{A}$ and peonidin-3-Glc-Ac, which contributed to the decreased $\mathrm{TAC}_{\mathrm{CAL}}$ of these wines. These changes in $\mathrm{TAC}_{\mathrm{CAL}}$ of the wines as a result of the pre-fermentation maceration treatments were relatively small, subsequently not affecting the $\mathrm{TAC}_{\mathrm{M}}$ in comparison to the control wine.

Pre-fermentation maceration resulted in no changes in wine hue $\left(h^{*}\right)$ for any of the vintages, although previously pre-fermentation maceration at 4 or $10^{\circ} \mathrm{C}$ resulted in changes in wine hue towards purple-red for Pinot noir wines (Heatherbell et al., 1994; Watson et al., 1994). The wine hues were in the magenta-red range for the 2000 and 2001 wines, while the 2002 wines had orange-red hues. None of the treatments improved or impaired the colour saturation of wines compared to the control wines. Small differences in $a^{*}$ obtained for the 2001 and 2002 wines, produced according to the $10^{\circ} \mathrm{C} / 4$ days protocol, did not affect the colour saturation or lightness in comparison to the control wines. The relative increase in $a^{*}$ which in turn resulted in lower $L^{*}$ for the 2002 wines produced according to the $15^{\circ} \mathrm{C} / 2$ days protocol, is attributed to the increase in vitisin A content of the wines. Prefermentation maceration at $15^{\circ} \mathrm{C}$ lasting 7 days resulted in Syrah wines with lower $\mathrm{L}^{*}$ values than a wine made without this step (Gómez-Míguez et al., 2006). This increase in vitisin A content did not, however, influenced the wine hue, despite the fact that vitisin A has an orange-red hue (Bakker \& Timberlake, 1997). In these cases, as was seen for the vintage-related variation in chromaticity, the anthocyanin and co-pigment content could not explain the variation in colour.

The pre-fermentation maceration treatments at $10^{\circ} \mathrm{C}$ and the $15^{\circ} \mathrm{C} / 1$ day treatment have been shown to increase the overall wine quality (Marais, 2003a). All treatments at $10^{\circ} \mathrm{C}$ also increased the berry/plum intensity of wines, although no increase in acetate ester concentrations was observed. Some pre-fermentation maceration treatments at $15^{\circ} \mathrm{C}$ decreased the acetate ester concentration of the wines without detrimental effects to the overall wine quality and berry/plum intensity.

\section{Juice/Skin Mixing during maceration}

Campbell (1991) found that a wine made with a commercial rotary fermenter yielded higher total phenol and total anthocyanin contents compared to either punching-down or pumping-over treatments. This could be due to blades in the rotary fermenter that cuts the grape skins and, therefore, increase extraction. In the present study, however, the rotor and punching-down treatments mostly resulted in wines with a similar phenolic composition. The pumping-over treatment is a less aggressive mixing action and was therefore the least effective in extracting phenolic compounds from the pomace as also found by Marais (2003b).

A factor influencing the phenolic composition of the wines is the greater degree of oxygen contact for the wines produced according to the pumping-over protocol compared to the punching-down and rotor protocols. The pumping-over treatment will also introduce more oxygen into the fermenting must than the punching-down treatment. Addition of oxygen can be beneficial to the yeast growth and metabolism (Sablayrolles \& Barre, 1986), but could also cause oxidation and subsequent polymerisation of phenolic compounds which could precipitate (Ribéreau-Gayon, 1986). This phenomenon probably contributed to the reduced concentrations of some individual anthocyanins and flavan-3-ols, as well as the monomeric and polymeric anthocyanin contents ( $\mathrm{pH}$ shift), observed for pumping-over wines compared to the other wines in 2000 and 2002. The same trend was not observed for the 2001 wines. In commercial winemaking, pumping-over in 
a closed system should not introduce as much oxygen as the small-scale procedure that was used in this study.

Increased mixing frequency is expected to increase the extraction of phenolic compounds due to better contact between the fermenting grape must and the pomace. Overall only small differences between the mixing frequencies were observed as was also noted by Marais (2003b). Only the extraction of flavonols was consistently favoured by the higher treatment frequency, while increased extraction of some flavan-3-ols was obtained, depending on the vintage. The phenolic acid content was affected differently for the 2001 and 2002 vintages with more frequent mixing, either increasing extraction of tartaric acid esters of hydroxycinnamic acids (caftaric and coutaric acid), or leading to a breakdown of these derivatives to caffeic and $p$-coumaric acid, respectively. The extraction of monomeric anthocyanins was not affected by mixing frequency.

The pumping-over treatment was the least effective in obtaining a wine with a high antioxidant capacity. This could be expected from their lower phenolic content, especially in terms of anthocyanin, flavan-3-ol and flavonol contents. Additionally, the low polymeric anthocyanin ( $\mathrm{pH}$ shift), coloured and non-coloured polymer (HPLC) contents of these wines also contributed to their low $\mathrm{TAC}_{\mathrm{M}}$, as indicated by their low $\mathrm{TAC}_{\mathrm{R}}$. The high $\mathrm{TAC}_{\mathrm{M}}$ of the 2000 wines, produced according to the rotor protocol, could be explained by their high total flavan-3-ol content (DAC). Phenolic acids and anthocyanins are the major contributors to the $\mathrm{TAC}_{\mathrm{CAL}}$ of wines, irrespective of the mixing treatment, with flavan-3-ols and flavonols playing a minor role. However, the contribution of flavan-3-ols to the $\mathrm{TAC}_{\mathrm{CAL}}$ of wines was underestimated, as only (+)-catechin and procyanidin B1 are taken into account.

Mixing frequency did not affect the $\mathrm{TAC}_{\mathrm{M}}$ of the 2000 and 2001 wines, which is explained by no significant differences in total phenol content. Mixing frequency also did not affect the $\mathrm{TAC}_{\mathrm{CAL}}$ of the 2001 and 2002 wines, despite the antioxidant capacity contribution of phenolic acids being higher and lower for the wines made with mixing every hour in 2001 and 2002, respectively. The differences in phenolic acid contribution to the $\mathrm{TAC}_{\mathrm{CAL}}$ is attributed to differences in caftaric and coutaric acid content. Caftaric acid has a relatively low antioxidant potency, while coutaric acid did not show any antioxidant effect (De Beer et al., 2006a). The mixing frequency also did not affect the $\mathrm{TAC}_{\mathrm{R}}$ of the 2001 wines. The higher $\mathrm{TAC}_{\mathrm{M}}$ of the 2002 wines, made with hourly mixing was due to higher non-coloured polymer and unknown compound content as no significant difference in $\mathrm{TAC}_{\mathrm{CAL}}$ was observed.

The pumping-over treatment not only produced wines with lower phenolic content and antioxidant capacity; their colour was also affected. Their colour was lighter (higher $L^{*}$ ) with less saturation (lower $C^{*}$ ), largely due to lower $a^{*}$ and lower $b^{*}$ values, although this was only true for the 2000 and 2002 wines. This is mainly attributed to their lower polymeric and total anthocyanin contents ( $\mathrm{pH}$ shift). In terms of individual anthocyanins, the malvidin-3-Glc, vitisin A, peonidin-3-Glc, malvidin-3-Glc-Ac and malvidin-3-Glc-Coum contents were lower in the 2002 wines. Decreased co-pigmentation due to their lower flavan-3-ol and flavonol contents, would also contribute to their lower $C^{*}$ values. The pumping-over treatment resulted in wines with red-magenta hues in 2002, while the hues obtained with the punching-down and rotor treatments were shifted to magenta-red.
By increasing the mixing frequency of the juice and pomace during maceration, the hue of the final wine was less "blue", than when 3-hourly mixing was used. No change in colour saturation was observed. A higher degree of co-pigmentation, due to a higher co-pigment content as represented by flavan-3-ol (DAC) and the individual flavonols, quercetin-3-Glc and quercetin-3-Rham contents, together with a monomeric anthocyanin content (HPLC) that was not affected by mixing frequency, caused this yellowing shift in hue.

Previously, Marais (2003b), analysing the same wines as in the present study, reported that the rotor action resulted in wines with higher concentrations of acetate esters than a punching-down or pumping-over action. This caused lower overall sensory quality and berry/plum intensity. Differences in mixing frequency did not significantly affect the acetate ester content, overall quality or berry/plum intensity of the wines.

\section{CONCLUSIONS}

Pre-fermentation maceration shows potential to improve the colour of Pinotage wines, but does not affect the TAC or phenolic content in a consistent manner, with most treatments resulting in no difference in TAC compared to the control wines. This technique, could, however, be used to increase the quality of Pinotage wines (shown previously), with no detrimental effects to the TAC. On the other hand, both punching-down and rotor juice/skin techniques resulted in wines with higher TAC and phenolic content than the pumping-over treatment in two out of the three vintages investigated, although trends for phenolic composition were different between vintages. The pumping-over wines also exhibited less favourable objective colour parameters. However, all the mixing techniques were suitable for producing high quality wines when taking all the objective quality parameters into account, while high sensory quality was demonstrated previously. The frequency of mixing increased the measured TAC in only one vintage, while most phenolic contents were not affected. The pumping-over treatment during maceration should therefore be avoided when production of high TAC wines is the aim, while increased mixing frequency may increase phenolic extraction depending on the grape berry composition.

\section{LITERATURE CITED}

Asen, S., Stewart, R.N. \& Norris, K.H., 1972. Co-pigmentation of anthocyanins in plant tissues and its effect on color. Phytochem. 11, 1139-1144.

Bakker, J. \& Timberlake, C.F., 1997. Isolation, identification, and characterization of new color-stable anthocyanins occurring in some red wines. J. Agric. Food Chem. 45, 35-43.

Campbell, C., 1991. A comparison of the use of open, closed and rotary fermenters for red wine production. Wine Ind. J. November, 275-277.

Castillo-Sánchez, J.J., Mejuto, J.C., Garrido, J. \& García-Falcón, S., 2006. Influence of winemaking protocol and fining agents on the evolution of the anthocyanin content, colour and general organoleptic quality of Vinhão wines. Food Chem. 97, 130-136.

Chen, L.-J. \& Hrazdina, G., 1981. Structural aspects of anthocyanin-flavonoid complex formation and its role in plant color. Phytochem. 20, 297-303

Clare, S.S., Skurray, G. \& Shalliker, R.A., 2004. Effect of pomace-contacting method on the concentration of cis- and trans-resveratrol and resveratrol glucoside isomers in wine. Am. J. Enol. Vitic. 55, 401-406.

De Beer, D., Joubert, E., Marais, J. \& Manley, M., 2006a. Unravelling the total antioxidant capacity of Pinotage wines: Contribution of phenolic compounds. J. Agric. Food Chem. 54, 2897-2905. 
De Beer, D., Joubert, E., Marais, J., Van Schalkwyk, D. \& Manley, M., 2006b. Climatic region and vine structure: Effect on Pinotage wine phenolic composition, total antioxidant capacity and colour. S. Afr. J. Enol. Vitic., 27(2), 151-166.

Eagerman, B.A., Clydesdale, F.M. \& Francis, F.J., 1973. Comparison of color scales for dark colored beverages. J. Food Sci. 38, 1051-1055.

Fischer, U., Strasser, M. \& Gutzler, K., 2000. Impact of fermentation technology on the phenolic and volatile composition of German red wines. Int. J. Food Sci. Technol. 35, 81-94.

Gómez-Míguez, M., Gonzáles-Miret, M.L. \& Heredia, F.J., 2006. Evolution of colour and anthocyanin composition of Syrah wines elaborated with pre-fermentative cold maceration. J. Food Eng., in press (doi:10.1016/j.jfoodeng.2006.01.054).

Gonnet, J.-F., 1999. Colour effects of co-pigmentation of anthocyanins revisited 2. A colorimetric look at the solutions of cyanin co-pigmented by rutin using the CIELAB scale. Food Chem. 66, 387-394.

González-Manzano, S., Rivas-Gonzalo, J.C. \& Santos-Buelga, C., 2004. Extraction of flavan-3-ols from grape seed and skin into wine using simulated maceration. Anal. Chim. Acta 513, 283-289.

Heatherbell, D., Dicey, M., Goldsworthy, S. \& Vanhanen, L., 1997. Effect of prefermentation cold maceration on the composition, color and flavor of Pinot Noir wine. In: Henick-Kling, T., Wolf, T.E. \& Harkness, E.M. (eds). Proc. 4th Int. Symp. Cool Climate Vitic. Enol., Rochester, USA. pp VI 10-VI 17.

Leone, A.M., La Notte, E. \& Antonacci, D., 1983. Some characteristics of polyphenolic substances in red wines obtained by different processes of maceration. In: Cantarelli, C. \& Peri, C. (eds). Progress in Food Engineering. ForsterVerlag, Switzerland. pp. 267-277.

Marais, J., 2003a. Effect of different wine-making techniques on the composition and quality of Pinotage wine. I. Low-temperature skin contact prior to fermentation. S. Afr. J. Enol. Vitic. 24, 70-75.

Marais, J., 2003b. Effect of different wine-making techniques on the composition and quality of Pinotage wine. II. Juice/skin mixing practices. S. Afr. J. Enol. Vitic. 24, 76-79.

Marais, J. \& Rapp, A., 1988. Effects of skin-contact time and temperature on juice and wine composition and wine quality. S. Afr. J. Enol. Vitic. 9, 22-30.

McMahon, H.M.M., Zoecklein, B.W. \& Jasinski, Y.W., 1999. The effects of prefermentation maceration temperature and percent alcohol $(\mathrm{v} / \mathrm{v})$ at press on the concentration of Cabernet Sauvignon grape glycosides and glycoside fractions. Am. J. Enol. Vitic. 50, 385-390.

McMurrough, I. \& McDowell, I., 1978. Chromatographic separation and automated analysis of flavonols. Anal. Biochem. 91, 92-100.

Peng, Z., Iland, P., Oberholster, A., Sefton, M.A. \& Waters, E.J., 2002. Analysis of pigmented polymers in red wine by reversed phase HPLC. Aust. J. Grape Wine Res. 8, 70-75.
Poussier, M., Guilloux-Benatier, M., Torres, M., Heras, E. \& Adrian, M., 2003. Influence of different maceration techniques and microbial enzymatic activities on wine stilbene content. Am. J. Enol. Vitic. 54, 261-266.

Re, R., Pellegrini, N., Proteggente, A., Pannala, A., Yang, M. \& Rice Evans, C.A., 1999. Antioxidant activity applying an improved ABTS radical cation assay. Free Radic. Biol. Med. 26, 1231-1237.

Reynolds, A., Cliff, M., Girard, B. \& Kopp, T.G., 2001. Influence of fermentation temperature on composition and sensory properties of Semillon and Shiraz wines. Am. J. Enol. Vitic. 52, 235-240.

Ribéreau-Gayon, P., 1986. Phenolics in grapes and wine. In: Lee, T. (ed.). Proc. 6th Aust. Wine Ind. Techn. Conference, AIP, Adelaide, Australia.

Ribéreau-Gayon, P. \& Stonestreet, E., 1965. Le dosage des anthocyanes dans les vins rouges. Bull. Soc. Chim. 9, 2649-2652.

Ribéreau-Gayon, P., Dubourdieu, D., Donèche, B. \& Lonvaud, A., 1999. Red winemaking. In: Handbook of Enology: The Microbiology of Wine and Vinifications, vol 1. John Wiley \& Sons, Ltd, Chicester, UK. pp 295-358.

Sablayrolles, J.M. \& Barre, P., 1986. Evaluation of oxygen requirement of alcoholic fermentations in simulated enological conditions. Sci. Aliments 6, 373-383.

Salinas, M.R., Garijo, J., Pardo, F., Zalacain, A. \& Alonso, G.L., 2003. Color, polyphenol, and aroma compounds in rose wines after prefermentative maceration and enzymatic treatments. Am. J. Enol. Vitic. 54, 195-202.

Salinas, M.R., Garijo, J., Pardo, F., Zalacain, A. \& Alonso, G.L., 2005. Influence of prefermentative maceration temperature on the colour and the phenolic and volatile composition of rosé wines. J. Sci. Food Agric. 85, 1527-1536.

Singleton, V.L. \& Rossi, J.R., 1965. Colorimetry of total phenols with phosphomolybdic phosphotungstic acid reagents. Am. J. Enol. Vitic. 16, 144-158.

Sun, B.S., Pinto, T., Leandro, M.C., Ricardo da Silva, J.M. \& Spranger, M.I., 1999. Transfer of catechins and proanthocyanidins from solid parts of the grape cluster into wine. Am. J. Enol. Vitic. 50, 179-184.

Sun, B., Spranger, I., Roque do Vale, F., Leandro, C. \& Belchior, P., 2001. Effect of different winemaking technologies on phenolic composition of Tinta Miuda red wines. J. Agric. Food Chem. 49, 5809-5816.

Villaño, D., Fernández-Pachón, M.S., Troncoso, A.M. \& García-Parilla, M.C. 2006. Influence of enological practices on the antioxidant activity of wines. Food Chem. 95, 394-404.

Watson, B., Price, S., Ping Chen, H., Young, S., Lederer, C. \& McDaniel, M., 1997. Fermentation practices in Pinot Noir: Effects on color, phenols, and wine quality. In: Henick-Kling, T., Wolf, T.E. \& Harkness, E.M. (eds). Proc. 4th Int. Symp. Cool Climate Vitic. Enol., Rochester, USA. pp VI 18-VI 23. 